University of Louisville

ThinkIR: The University of Louisville's Institutional Repository

Electronic Theses and Dissertations

$12-2012$

\title{
Turkish housing policies : a case study on mass housing provision in the last decade.
}

Salih Ozgur Sarica 1983-

University of Louisville

Follow this and additional works at: https://ir.library.louisville.edu/etd

\section{Recommended Citation}

Sarica, Salih Ozgur 1983-, "Turkish housing policies : a case study on mass housing provision in the last decade." (2012). Electronic Theses and Dissertations. Paper 1264.

https://doi.org/10.18297/etd/1264

This Master's Thesis is brought to you for free and open access by ThinkIR: The University of Louisville's Institutional Repository. It has been accepted for inclusion in Electronic Theses and Dissertations by an authorized administrator of ThinkIR: The University of Louisville's Institutional Repository. This title appears here courtesy of the author, who has retained all other copyrights. For more information, please contact thinkir@louisville.edu. 
TURKISH HOUSING POLICIES: A CASE STUDY ON MASS HOUSING PROVISION IN

THE LAST DECADE

\begin{abstract}
By
Salih Ozgur Sarica

M.S., Kocaeli University, Turkey, 2008

A Thesis

Submitted to the Faculty of the

College of Arts and Sciences of the University of Louisville

In Partial Fulfillment of the Requirements

For the Degree of
\end{abstract}

Master of Public Administration

Department of Urban and Public Affairs

University of Louisville

Louisville, Kentucky

December 2012 
Turkish Housing Policies: A Case Study on Mass Housing Provision in the Last Decade By

Salih Ozgur Sarica

M.S., Kocaeli University, 2008

A Thesis Approved on

December 5, 2012

By the following Thesis Committee:

Steven C. Bourassa

Thesis Director

Janet Marie Kelly

Wei Song 


\section{ACKNOWLEDGMENTS}

I would like to thank Dr. Steven Bourassa for his guidance, help and patience. I would also like to thank the other committee members, Dr. Janet Marie Kelly and Dr. Wei Song, for their advice and support.

I would like to acknowledge the financial assistance of the Turkish Ministry of National Education that made my education at the University of Louisville and this thesis possible.

I wish to thank my family and friends in Turkey for their patience and encouragement. Also, I am very thankful to my friends in the United States for their help and friendship. 


\begin{abstract}
TURKISH HOUSING POLICIES: A CASE STUDY ON MASS HOUSING

PROVISION IN THE LAST DECADE
\end{abstract}

Salih Ozgur Sarica

December 5, 2012

Most industrial countries face with some form of housing problems. As a result, each state has adopted a variety of housing policies. Policy methods of government authorities in meeting the housing gap and addressing the low income families' housing needs differ from one country to another. In Turkey, the housing policies have not been effective to respond the housing needs of low- and middle-income families until the recent decades. Turkish Mass Housing Administration (TOKI), which was established in 1984, accelerated its mass housing provision in recent years. Through law amendments and administrative reforms in 2003 and 2004, TOKİ as a central government organization became the main actor in the housing sector in Turkey.

The rapid increase of its mass housing production in the last decade has attracted the attention of many urban scholars, professional real estate organizations, and other non-profit organizations in terms of whether such mass housing provision changes the urban life in a better way and fills the housing gap without any negative externalities. Thus, this study builds upon the recent practices of Mass Housing Administration (TOKI) 
and aims to reveal its nature by investigating the determinants and possible outcomes of recent mass housing production.

Proliferation of mass housing projects in the last ten years received some criticism by scholars and the civil organizations. Particularly, the methods being used in the housing provision are questioned in most housing studies in Turkey as they bring not only significant amount of housing supply but also some negative implications to the Turkish society. Based on discussion in the literature, it is hypothesized that population increase, political support, available public lands, and tenancy rates are the determining factors; net migration increase, real estate company shutdowns, more land use for housing, and more political support to the administration are the possible outcomes of mass housing provision by TOKI

The findings of this study indicate that the mass housing provision of the past decade is a positive function of political gains, metropolitan areas, and the destruction of recent major earthquakes. Also, TOKI's housing provision seems to have impacted the real estate sector in a negative way while it helped the ruling party to increase its political support in the last five years. 
TABLE OF CONTENTS

PAGE

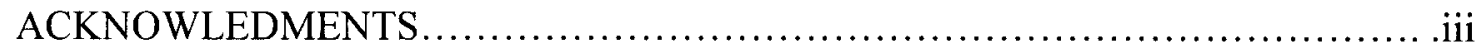

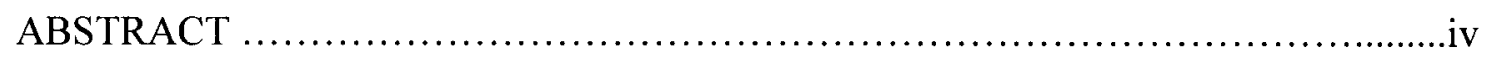

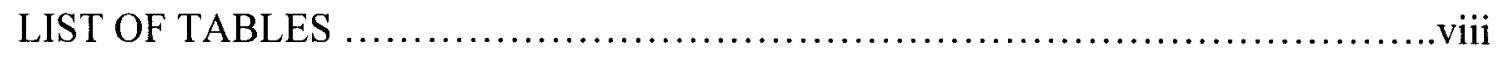

LIST OF FIGURES ................................................................ ix

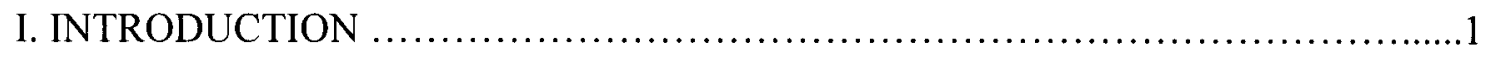

II. HISTORY OF TURKISH URBANIZATION AND HOUSING POLICIES.......... 9

1923-1950: State Industrialization and First Housing Patterns ................. 10

1950-1980: Housing Problems of Rural Migrants and Shanty Towns............12

Post-1980s: Neo-Liberal Era and the Beginning of Mass Housing ...............16

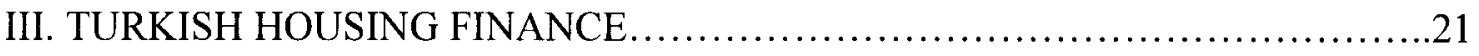

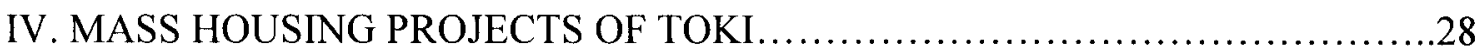

V. LITERATURE REVIEW ON MASS HOUSING PRACTICES

IN THE LAST DECADE..................................................... 
VI. HYPOTHESIS

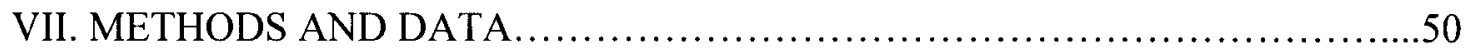

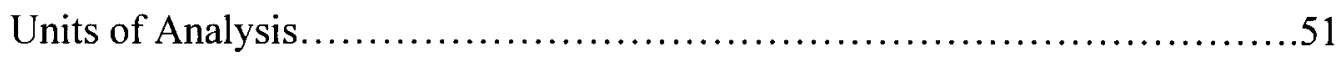

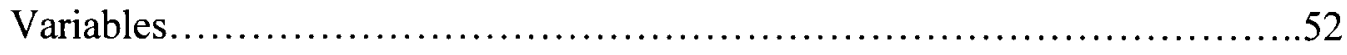

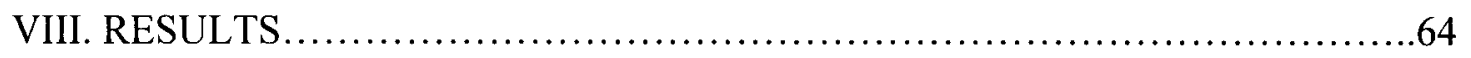

Bivariate Relationships (Model I) .........................................64

Regression Analysis (Model I) ...........................................66

Bivariate Relationships (Model II) ....................................69

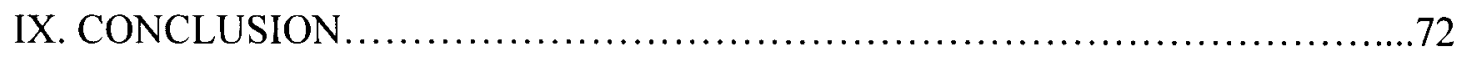

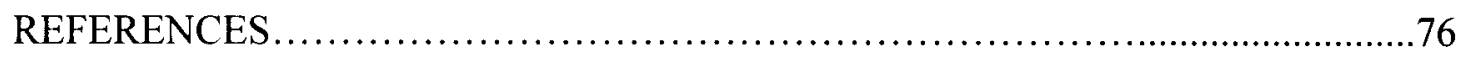

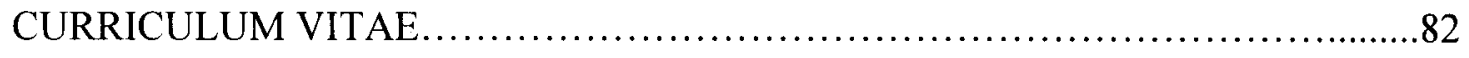




\section{LIST OF TABLES}

TABLE

PAGE

1. The proportion and growth of urban-rural population in Turkey

2. Shanty towns (gecekondu) population in major Turkish cities (early 1960s).

3. Housing production financially assisted by public institutions

4. The Mass Housing Administration (TOKI)'s partnerships. .25

5. TOKI project implementations (2003 to 2012)

6. Social facilities constructed by TOKI between 2003 and $2012 \ldots \ldots \ldots \ldots \ldots \ldots \ldots 32$

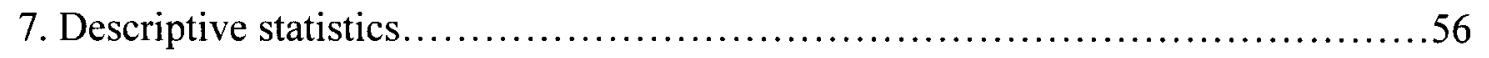

8. Correlation matrix, dependent and independent variables for model I...............65

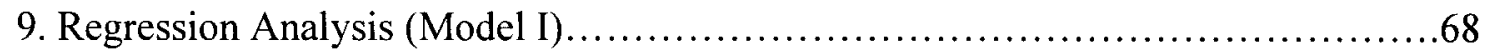

10. Correlation matrix, variables for model II.................................. 71 


\section{LIST OF FIGURES}

FIGURES

PAGE

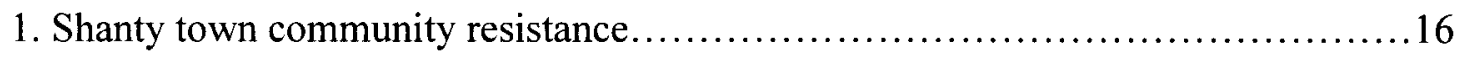

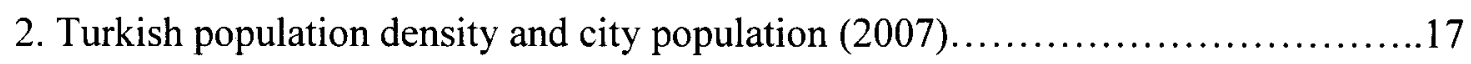

3. Urban renewal examples by TOKI......................................... 34

4. A mass housing project for low income population.............................36

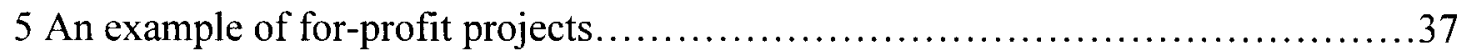

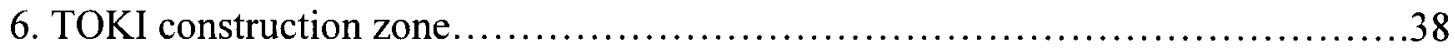

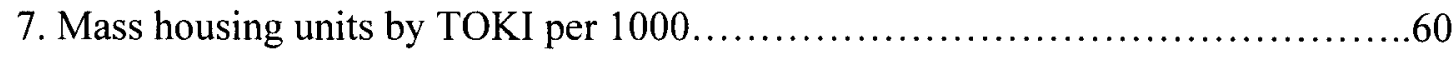

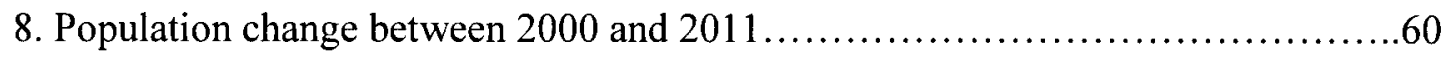

9. The share of public lands in total areas...................................61

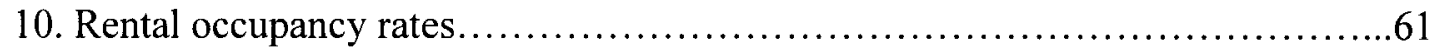

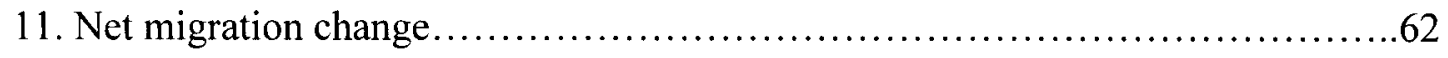

12. The rate of closed real estate companies...............................62

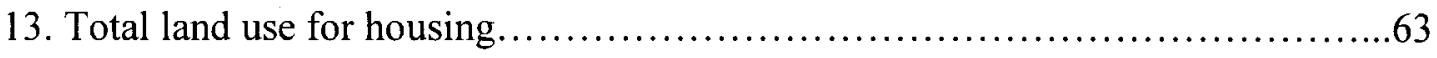




\section{FIGURES}

PAGE

14. General election results for the ruling administration.........................63 


\section{CHAPTER I}

\section{INTRODUCTION}

"Every citizen has the right to live in a healthy and balanced environment (article 56)...the State shall take measures to meet the needs of housing within the framework of a plan which takes into account the characteristics of cities and environmental conditions and shall support mass housing projects (article 57)" The Constitution of the Republic of Turkey (1982)

"Mass Housing Administration (TOKI) offers hope to millions of Turkish citizens who would not otherwise have an opportunity to own their home, or live in a neighborhood with modern schools, business areas, hospitals, mosques and libraries" TOKI

Housing is one of the essential needs of human beings. Recognition of the housing need as a right has lately occurred in the middle of $20^{\text {th }}$ century. As stated in Article 25 of "Universal Declaration of Human Rights" by United Nations in 1948; "everyone has the right to a standard of living adequate for the health and well-being of himself and of his housing..". A more binding contract among UN members, which is the International Covenant on Economic, Social and Cultural Rights signed in 1966, enforces the recognition of housing as a right. By this international contract, each member is expected to recognize that housing is a basic requirement of sustaining well-being of life. 
To begin with, there have been some socio-economic dynamics behind the emergence of the housing problem. The rise of the industrial revolution brought rapid urbanization creating housing problems due to the increasing population mainly in cities. The rapid growth of population increased the need for housing as it made the existing housing stocks inadequate in industrial cities. Since construction was not developed enough and citizens could not afford market prices of the existing stock, states began to take on the housing issue as one of their duties. Furthermore, particularly at certain breaking points in history, the housing problem has come to an alarming level. These breaking points have mostly been times of economic crises or wars affecting primarily the housing market. Thus, especially in the second half of $20^{\text {th }}$ century, government subsidized housing has come to be more pronounced in the context of social safety net policies. Most industrial societies have somewhat taken care of their housing problems by giving necessary support to those who were not able to live in a standard quality dwellings at urban environments (Keles, 1983).

Rapidly changing socio-economic conditions require new approaches in state housing policies. According to Oxley (2000, p.2),

If housing conditions are inadequate, it might be concluded that this is because some households are unable to demand housing of an acceptable standard. If this inability is due to a lack of resources, then resources might be redistributed to those who lack effective demand. The redistribution could take the form of additional income or housing supplied at submarket prices. 
Beyond being a shelter, housing has various functions. It carries multi functional characteristics for both individuals and the society. Among these characteristics, housing is a produced commodity and an investment good that provides security to its dwellers (Tekeli, 1996: pp. 3-7). Since housing is a different commodity from most of the other commodities, it has also some unique characteristics. For instance, it is subject to many institutional regulations imposed by various level of government (Türel, 2006). Also, housing gives individuals a choice of neighborhood, an access to workplaces and to a variety of local services such as schools (Harsman and Quigley, 1991, p. 2)

Housing policy is dependent on the ruling government's political ideology. The goals and objectives of housing policy show significant differences from one country to another. Regardless of their orientation, all developed and developing countries are faced with housing problems (Balchin, 1996, p. 1)

Most governments favoring free market economy usually involve less state intervention, give limited support to affordable housing provision, and support owner-occupation and private landlordism. Conversely, governments in which their political orientation is to recognize and correct market failures prefer to interfere in the market, give responsibilities to local authorities and non-profit organizations to enable them to provide affordable housing and to control the distribution of housing resources equally across and within tenures.

Regardless of their political orientation toward free market perspectives, most industrial countries face with some form of housing problems. As a result, each state has adopted a variety of housing policies. According to Harsman and Quigley (1991, p. 1): 
The production, consumption, financing, distribution and location of dwellings are controlled, managed and financed in complex ways. In fact, compared to other economic commodities, housing is perhaps the most tightly controlled of all consumer goods. (...) The policies have been adopted for a variety of economic, political, ideological, and historical reasons. The application of these policies affects the view and development of urban areas, the economic well-being of households, and their social environments.

All in all, governments have some roles and objectives in regard to housing for many reasons. These are obtaining the best use of existing housing resources, ensuring enough housing for all citizens, determining the location of new housing, being responsible for the housing needs of special groups, and influencing the policies of local authorities in allocating housing provision (Harvey, 1981, pp. 195-196).

Policy methods of government authorities in meeting the housing gap and addressing the low income families' housing needs differ from one country to another. Building affordable housing blocks to sell or operate, subsidizing rental payments (vouchering), or enabling affordable housing credits have been among the policy options. In the US, public housing was subsidized to meet the housing needs of low income families after the Second World War. Such government-operated buildings have later come to forefront of public discussions as they were considered to be unhealthy environments with poverty and race being concentrated and having less access to most socio-economic advantages. After 1990s, most public housing projects were demolished under the HOPE VI program in an attempt to relieve such drawbacks of housing subsidies. American housing policies for the low income are now more oriented toward 
poverty de-concentration and racial heterogeneity. Instead of high rise projects, tenantbased voucher programs are the primary means of providing subsidies to the low income (Vale, 2002).

In the UK, social rented housing has been the essential means of government subsidies to low income households. In 1979, "93 percent of social rented housing was owned by local authorities and New Towns corporations". However, the subsidy system was reorganized by the government in 1980s. "As a result, especially since 1988, almost all new social rented housing has been provided within the Housing Association (HA) and particularly the Registered Social Landlord (RSL) sector" (Whitehead, 2007, p. 57). Through changes in government policies and economic systems all around the world, the social rented housing in the UK lost its importance and the housing policy was more based upon owner occupancy. The major decline in social rented housing has occurred after the "Right to Buy" policy which was introduced in the Housing Act enacted in 1980. "Nearly 1.8 million dwellings have been sold to the sitting tenants after 1980s" (Whitehead, 2007, p. 56).

Affordable housing provision by the Turkish government, on the other hand, emerged in the 1980s. Increasing urban population due to rural migration has called for more affordable housing supply. As the Turkish government could not provide effective subsidies to fill the housing gap, increasing demand for housing in the second half of the 20th century resulted with illegal housing settlements (gecekondu) on public lands. While western societies have to some extent produced low-income housing projects, the Turkish government could only keep silent and provide amnesties to such illegal settlements. Such proliferation of squatter towns has brought many socio-economic and 
environmental burdens to the cities such as inefficient urban services, congestion and increasing urban density problems. As a result, many laws and regulations were enacted regarding the housing issue. However, these laws weren't enough to solve the emerging problems (Keles, 1983).

Starting with 1960s, housing cooperatives and newly emerged real estate companies have started producing 5 to 8 -floor apartment buildings at a mass scale. Such housing provision was further accelerated by the financial subsidies of the Mass Housing Administration (TOKI) which was established in the beginning of the 1980s. Between 1984 and 2003, the basic strategy of TOKI has been to provide affordable loans for the use of individuals and housing cooperatives, and its direct-investment capacity on housing supply has been up to a certain limit.

However, in the last ten years, the housing investments of the public sector have increased considerably as TOKİ began to produce on its own and became as the main actor in housing sector. Especially the changes in mass housing regulations in 2003 gave an immense authorization to TOKI and made its policy methods more flexible. The share of the Administration in total housing provision increased considerably and reached to 10 percent in total production.

Since the Turkish government does not own and operate housing buildings except for lodging for public servants, the way of housing subsidy by Turkish government authorities is generally called "mass housing" as it helps to produce and sell housing units on a mass scale. 
The rapid increase of mass housing production in the last decade has attracted the attention of many urban scholars, professional real estate organizations, and other non-profit organizations in terms of whether such mass housing provision changes the urban life in a better way and fills the housing gap without any negative externalities. The subject of mass housing is still young in Turkey and its practices are steadily becoming more apparent than ever. Over the last ten years, the level of mass housing production by TOKI has reached up to 500,000 housing units, and still continues.

In the light of such concern on mass housing, this study builds upon the recent practices of Mass Housing Administration (TOKI) and aims to reveal its nature by investigating the determinants and possible outcomes of recent mass housing production.

In Chapter II, the history of Turkish urbanization and housing policies will be examined to set the ground for a discussion of mass housing. It is crucial to see the historical background of urbanization and housing policies of Turkey since their characteristics give us important clues about the recent housing provision

In the third chapter, the study focuses on the Turkish housing finance system and its impact on the way that mass housing production is handled financially. Inadequacy of government organizations in housing finance and the lack of a robust financial system until the recent decades motivated the Mass Housing Administration to find different strategies in creating more effective housing finance system in Turkey.

Chapter IV mainly focuses on introducing the objectives and implementations of the Mass Housing Administration (TOKI), particularly the ones that occurred in the past decade. The radical changes in its role in the housing sector will be examined in detail. 
Proliferation of mass housing projects in the past decade received some criticism by scholars and the civil organizations. Particularly, the methods being used in the housing provision are questioned in most housing studies in Turkey as they bring not only significant amount of housing supply but also some negative implications to the Turkish society. Thus, the discussions in the Turkish literature will be reviewed in Chapter V.

Finally, Chapters VI through VIII consist of the study's research design and findings. The study aims to find out significant causal relationships between the mass housing provision and other relevant factors discussed in the literature. Two models are being designed to test the hypothesis. One is to investigate the determinant factors of recent mass housing provision while the second model looks for abnormal changes that might be affected by the recent practices of Mass Housing Administration (TOKI). 


\section{CHAPTER II}

\section{HISTORY OF TURKISH URBANIZATION AND HOUSING POLICIES}

After the collapse of Ottoman Empire, the Turkish Republic, founded in 1923, has adopted many radical changes including westernized regulations, a unitary government system, industrialized economic activities, modern social life, and so on. One of these radical reforms has involved initiating the industrial economy that would transform agricultural society into a modern urbanized population. The main focus of the founding regime was to catch up with western industrialization and civil reforms.

On the other hand, there have not been grounds for a strong private sector that could lead to a growing economy. Thus, the regime's priority has been to start with stateowned industrial investments so to prepare the way for a strong private economy. Such attempts and modernization of agriculture later catalyzed an urbanization process in which the agricultural population migrated to industrial zones where it faced housing problems and other pathologies of urban areas. Turkish urbanization and housing policies can be evaluated in three periods (Sengul, 2001, pp. 61-94): the period between 1923 and 1950 that included empowerment of state industry and housing needs for public servants; the 1950-1980 period that consisted of migration from agricultural places to urban areas at a moderate level and rising housing needs for the newcomers, and finally, the post1980s period that features privatization, real estate investments, and the start of mass housing projects. 


\section{3-1950: State Industrialization and First Housing Patterns}

This period involved re-establishing the socio-economic life of the Turkish population from the debris of Ottoman Era. Among the radical reforms, the founding regime in first decades re-configured economic activities to ensure that the country could catch up with western industrialization and capitalist society. Thus, it has been necessary to remove traditional barriers for putting this agenda in effect. For instance, western trade regulations and other civic reforms such as adopting the Latin alphabet and Gregorian calendar have passed in legislation during this period. Although the regime planted the first seeds of industrial economy through its statist initiatives, it was not until 1950s to have a strong private sector that could lead to constant economic growth (Savran, 1992, pp. 51-56).

Before the $1950 \mathrm{~s}$, there were not yet the pull-effects of city agglomeration for both the fledgling industrial sector and rural labor force to create today's urban areas (Coban, 2012, p. 60). Older cities' own population dynamics were sufficient to meet the labor demands of the first industrial initiatives. On the other hand, modernization of the agricultural economy that was accompanied by Marshall Plan's fiscal support started to show its effect upon rural workers from the 1950s. The Turkish urban population that was 23.5 percent of total population in 1935 increased to only 25 percent in 1950 . The urbanization rate was so low in this period that housing and other urban policies were not part of the central government's priorities (Sengul, 2001). 
Nevertheless, some housing practices between 1923 and 1950 are worth mentioning. First of all, population exchange between Greece and Turkey after World War One has called for a housing and settlement policy in order to meet the housing demands of Turkish migrants from Greek and other Balkan state territories. For this purpose, the central government established the short-lived Ministry of Exchange, Housing and Settlement in 1923 and almost 400,000 migrants were placed in either evacuated Greek houses or in new affordable housing units that were poorly constructed by the Ministry (Capa, 1990). Another exceptional concern for housing was dispersal of the Kurdish ethnic group that settled intensely in the southeast region. The regime's purpose was to obtain cultural harmony that would be a basis for a homogenous national identity. For this reason, the Settlement Law was passed in 1934. This law has provided the Kurdish population with conditional housing subsidies. They received housing support as long as they intended to settle near predominantly Turkish communities (Besikci, 1992, p. 435).

Furthermore, the number of public servants has increased as new reforms and public initiatives were enforced by new modern regulations that required more government institutions turning old trade hubs into quasi-bureaucratic cities. As a response to the housing needs of public servants, the Turkish government has provided extra credits to their wages and built housing quarters (lodgments) especially in the capital city, Ankara, where most government organizations located and the first city planning was implemented. Nevertheless, such attempts should not be considered as nation-wide exclusive practices but they were ad hoc and urgent necessities of state foundation in the early years. In addition to these policies, municipal governments were 
obligated to play a role in housing affairs, such as building housing units for municipal workers, but their practices only focused on land-use regulations and therefore unresponsive to the housing demands (Coban, 2012, p. 62). Eventually, this period was too early to involve exclusive housing policies except some ad hoc cases since there were not the necessary conditions for urbanization, and the government priorities were to initiate a sound national economy.

Table 1. The proportion and growth of urban-rural population in Turkey

\begin{tabular}{|lllll|}
\hline Years & Urban Population & $\%$ & Rural Population & $\%$ \\
\hline & & & & \\
1927 & $3,305,879$ & 24.2 & $10,342,391$ & 75.8 \\
1935 & $3,802,642$ & 23.5 & $12,355,376$ & 76.5 \\
1940 & $4,346,249$ & 24.4 & $13,474,701$ & 75.6 \\
1945 & $4,687,102$ & 24.9 & $14,103,072$ & 75.1 \\
1950 & $5,244,337$ & 25.0 & $15,702,851$ & 75.0 \\
\hline 1955 & $6,927,343$ & 28.8 & $17,137,420$ & 71.2 \\
1960 & $8,859,731$ & 31.9 & $18,895,089$ & 68.1 \\
1965 & $10,805,817$ & 34.4 & $20,585,604$ & 65.6 \\
1970 & $13,691,101$ & 38.5 & $21,914,075$ & 61.5 \\
1975 & $16,869,068$ & 41.8 & $23,478,651$ & 58.2 \\
1980 & $19,645,007$ & 43.9 & $25,091,950$ & 56.1 \\
1985 & $26,865,757$ & 53.0 & $23,798,701$ & 47.0 \\
1990 & $33,326,351$ & 59.0 & $23,146,684$ & 41.0 \\
2000 & $44,006,274$ & 65.0 & $23,797,653$ & 35.0 \\
& & & & \\
\hline
\end{tabular}

Source: Isik (2006, p. 60)

1950-1980: Housing Problems of Rural Migrants and Shanty Towns

After the 1950s, economic improvements and reforms started to show their effects on the urbanization process as they gave cities comparative advantages. The urban population has increased from 25 percent to 43.9 percent between 1950 and 1980 (see Table 1). Similar to the dynamics in other industrial societies, changes in production methods and government system have led to more populated city agglomerations in 
Turkey. The use of modern techniques in agriculture has diminished the need for labor force in the rural economy. Industrial production grew faster than agricultural production. Between 1954 and 1961, Turkish industrial growth rate was 4.3 percent whereas agricultural rate was only 1.8 percent (Boratav, 1990, pp. 312-323). Also, net wages of industrial workers and public servants were relatively higher than the earnings of rural workers while they were also taking advantage of the public services available in city areas (Keles et al., 2009, p. 120). Eventually, this period has involved a moderate level of migration from rural areas to cities, and housing problems aroused as the newcomers were to settle in.

Housing policies were not successful in responding to the needs of the growing urban population during this period. Only a small proportion of city dwellers were able to live in standard quality housing units. Lack of both private real estate and effective urban planning led most individuals to meet their housing needs by their own initiatives. Thus, people with low income ended up living in squatter houses (gecekondu) at the outer rings of major cities (see Table 2). The share of slum population in total urban population was 4.7 percent in 1955, and 26.1 percent in 1980 (Keles, 2010, pp. 493-494). There are two important factors behind the proliferation of shanty towns in Turkish city areas. First, industrialization and city economies were not strong enough to absorb all rural migrants into well-paid jobs. In these conditions where urbanization exceeds industrialization, rural migrants were either underemployed or hired in low-paid service jobs. The census data shows that the share of service sector in total employment was 15.4 percent in 1960 , and 29.5 percent in 1980 , whereas the industrial employment was only 9.6 percent and 12.5 percent in the same period (Boratav, 1990, p. 334). Ineffective state capitalism and 
a private sector that was based upon import-substitution and motivated by conventional trade customs were not able to produce the necessary capital to be reinvested for constant growth and new job opportunities. Secondly, government policies were unresponsive and to some point accommodating to the housing needs of slum residents who were left outside of the 1960s unionized labor force since the housing need was generally left to individual initiatives (Coban, 2012, pp. 65-66).

Table 2: Shanty towns (gecekondu) population in major Turkish cities (early 1960s)

\begin{tabular}{|lccc|}
\hline Major Cities & $\begin{array}{l}\text { Total Gecekondu } \\
\text { Population }\end{array}$ & $\begin{array}{l}\text { Total City } \\
\text { Population }\end{array}$ & Percentage \\
\hline Adana & & & \\
Ankara & 104,088 & 231,548 & 44.95 \\
Antakya & 384,500 & 650,067 & 59.22 \\
Bursa & 14,493 & 45,674 & 31.73 \\
Diyarbakir & 47,922 & 153,886 & 31.14 \\
Erzincan & 7,700 & 79,888 & 9.64 \\
Erzurum & 19,250 & 36,420 & 52.86 \\
Iskenderun & 31,625 & 90,069 & 35.11 \\
Istanbul & 23,513 & 62,061 & 37.89 \\
Izmir & 660,000 & $1,466,535$ & 45.0 \\
Mersin & 99,138 & 296,635 & 34.42 \\
Samsun & 4,928 & 68,485 & 3.19 \\
& 31,350 & 87,688 & \\
\hline
\end{tabular}

Source: Karpat (1976, p.11)

After the 1960s, housing came to be recognized as a right and part of government responsibilities although there was not intense direct government involvement in housing supply for low income families. Housing was first mentioned in the 1961 Turkish Constitution under the chapter of "right to medical care"; "The State shall take measures to provide the poor and low income families with dwellings that meet sanitary requirements" (Article 49). In the following years, the national five-year strategic plan 
covering the period between 1979 and 1983 reported that "housing and infrastructure are subject to public policies and, therefore, should not be seen as commodities in order to resolve rising problems". However, such premises on state documents and actual government practices were inconsistent at this period. Coban (2012) sheds lights on two important factors influencing the way government authorities respond to the housing problems. First, private businesses were motivated to keep wages low and so were reluctant to take on the burden of housing provision for low-income workers while they needed to have the working class settled around city areas in order to meet their labor demands. At the same time, the strong unionization trend and labor movements between 1960 and 1980 put immense pressure on the socio-political environment to provide the Turkish working class with better living conditions including sanitary housing. To give a well-known example, squatter housing communities started to demonstrate sharp resistance to municipal authorities to protect their poorly constructed dwellings even though these communities were mostly illegal settlements on either public or private land properties and government authorities had legal rights on these lands for the use of city projects (see Figure 1). Nevertheless, government agencies have mostly allowed illegal shanty town settlements and even provided zoning forgiveness during the election campaigns. Eventually, instead of providing housing subsidies for the poor either through public housing units or affordable credits, Turkish state authorities have chosen to balance business interests and the housing demands of the working class by permitting the proliferation of unsanitary and unplanned shanty towns and giving zoning forgiveness unless such lands' exchange value were so high in the market economy. This policy has, in fact, been the only option for the state given its limited budget for additional spending 
on housing and the fact that the shanty settlements at the urban edges were somewhat necessary for reproduction of the labor class in order to sustain the economy.

Figure 1. Shanty town community resistance

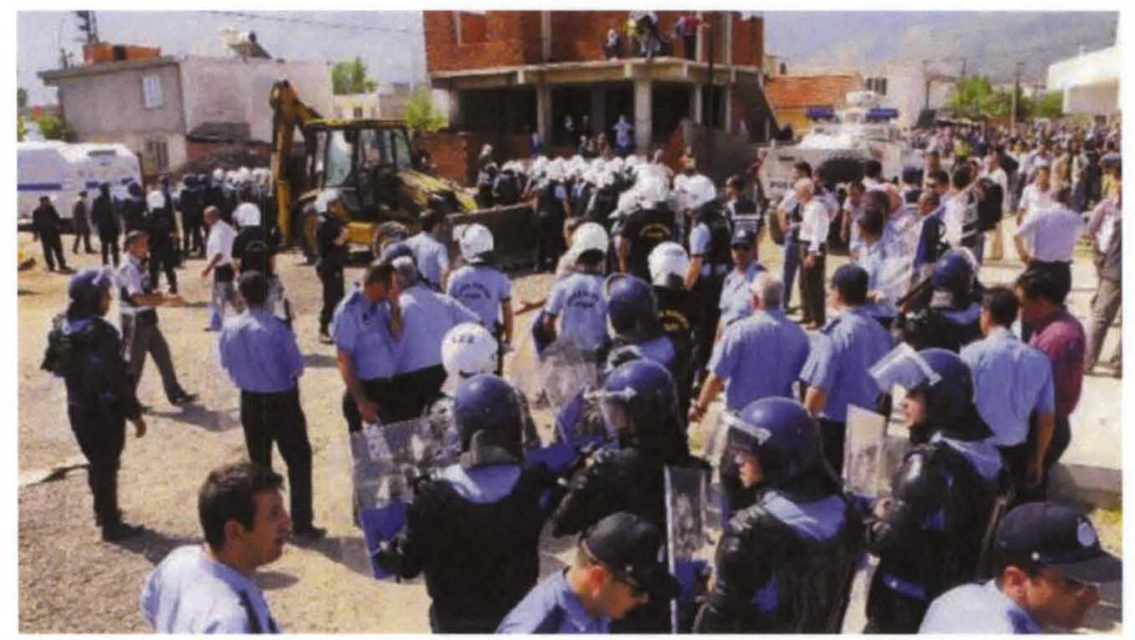

Source: Photo taken by Ilker Kilicaslan, Dogan News Agency, in 2012.

Such government failure on the housing issue was reported in official documents by the State Planning Organization in 1979:

Ineffectiveness of public sector on housing subsidy, low housing supply to increasing population, and high housing prices have led new migrants to live in squatter houses that surround major cities' edges. More than half of the population resides in such places.

\section{Post-1980s: Neo-Liberal Era and the Beginning of Mass Housing}

Urbanization has continued and first exceeded the share of rural population with the beginning of this period. Unlike earlier periods, the ongoing rural migration has changed its character and become more geographically selective. The conventional push- 
effect of rural poverty has gained an additional dynamic especially in east and southeast regions of Turkey, which is growing ethnic terrorism. Kurdish separatist groups have begun to intensify their terrorist attacks, making most villages unsafe and eventually emptying them in the southeast region. Thus, the direction of migration was west-bound. Such threats of terrorism still affect the region today and economic growth with its many advantages is, therefore, geographically skewed toward the middle and west part of the country (Isik, 2006, p.66). In fact, highly populated city areas and major industrial plants are located in Marmara (northwest) and Cukurova Region (mid-south) where industrial ports and trade hubs provide comparative advantages to city economies (see Figure 2).

Figure 2. Turkish population density and city population (2007)

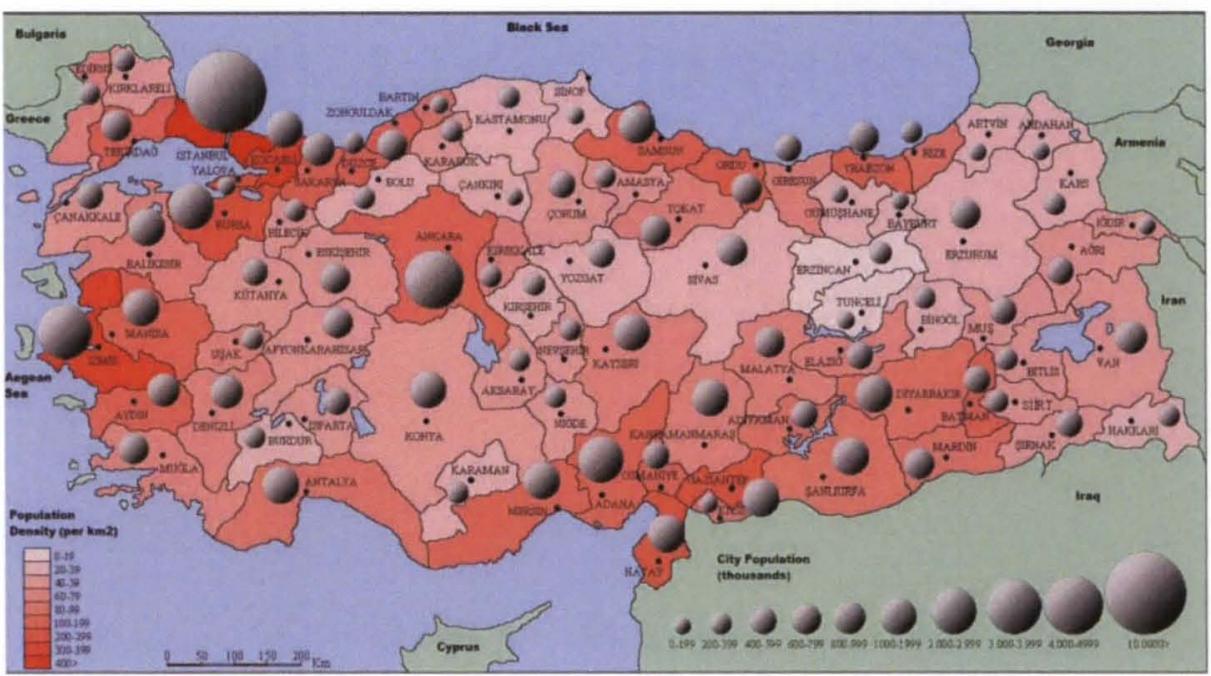

Source: TUIK (Turkish Statistical Institute).

Rural migrants' strong family relationships and cultural connections with people left in rural towns have given urbanization a multiplying effect. Those who already settled in urban areas have attracted their relatives and rural town fellows to urban areas by informing them about the advantageous of living in cities, finding them jobs, and 
teaching how to deal with the urban lifestyle. This has brought a new cultural term and a settlement pattern. People from the same rural areas or region have tended to live together in metropolitan communities by creating township associations. This is termed hemsehrilik in which rural migrants maintain their local cultures and help each other in metropolitan areas (Kurtoglu, 2005).

As urban areas received more rural migrants and had to house almost 70 percent of the Turkish population, housing problems rose to an alarming level because city economies could not provide affordable and decent housing supply in a mass quantity without government subsidies, especially for lower income population. Unplanned urbanization and increasing shanty settlements attracted more attention by the public, scholars, and government experts after the 1980s. The 1982 Turkish Constitution recognizes housing as a right in a distinct chapter:

The State shall take measures to meet the needs for housing, within the framework of a plan which takes into account the characteristics of cities and environmental conditions and supports community housing projects (Article 57).

However, when this article is compared with the one in the 1961 Constitution, there is no specific indication for the policy's target group, especially the poor. Setting no priority for the housing needs of lower income population was, in fact, a reflection of the regime's neo-liberal agenda. As such, most housing policies after the 1980s have been more market-oriented and intended for the middle and higher income population although they were not so much different than the earlier periods, and low-income housing subsidies have yet to become effective in recent years (Coban, 2012, p.74). 
The 1982 Constitution introduced a new mandate for the Turkish government: "The State shall support community housing projects". In fact, the state's accommodation for community housing was an important policy initiative in terms of healing the growing housing paucity but the purpose was to accelerate the real estate sector regardless of what income group benefits. Also, the housing market came to be recognized as a key sector in the economy as it provides new job opportunities and invigorates its input related industries (Oymen, 1985). In the following years, mass housing laws passed with an effort to increase housing supply in urban areas. The first law passed in 1981 and defined mass housing as about 750 to 1000 housing units produced at one time. Smaller the lot size that the housing cooperatives have in their construction plans meant more investment trust they could use. Also, in order to benefit from the credit and other advantages given by the law, these housing cooperatives had to include almost 20 to 25 percent of their total project cost as a down payment in their saving accounts, which was mostly collected from the buyers. Such housing model has many implications. First of all, oligopolistic real estate companies put large investments to the market, which left individual and traditional (build and sell) construction methods out of business. As such, the share of real estate investments in total industrial investments was 29.4 percent in 1977, 50.4 percent in 1989 (Boratav, 1995, pp.190-192). Furthermore, there have been a growing number of building societies whose its members used their savings for home ownership during the construction. The number of building societies increased from 14,872 to 38,450 between 1979 and 1998. Even though the mass housing law first appeared to aim at meeting the housing needs of low-income households, the credit requirements could only be met by the middle and higher income class who could afford the initial costs of 
the mass housing construction and could own their houses by completing the full payment in a short term. More realistic housing policy for low-income families has come with new arrangements to the mass housing system started in 2003. As this study's main focus is upon recent mass housing policies and their socio-economic implications, they will be examined in the following chapters in more detail. 


\section{CHAPTER III}

\section{TURKISH HOUSING FINANCE}

In Turkey, housing paucity has emerged as a primary issue due to fast urbanization since the 1950s. As in the other developing countries that experience a similar trend, Turkey has not adequately produced affordable housing as a response to increasing demands. The effects of high inflation, inadequacy of long term savings and the lack of a sound financial sector have made it impossible for individuals to meet their housing finance needs. On the other hand, government policies' strict dependence on a limited budget have not allowed for necessary and regular funding for housing finance (Akcay, 2003, p. 45). Thus, it has been much later than the western countries to make progress on housing finance as it depends on the economic conditions and the presence of a sound financial market (Ayan, 2011).

The first institution for housing finance was established in 1926, called Emlak Bankasi (Real Estate Bank) with the object of supporting families' housing purchase and providing necessary loans. Different than other public banks, Emlak Bankasi has initially provided long term home loans to families with interest rates being under the market level. However, most of the time, especially during the economic downturns, Emlak Bankasi and other public-private banks have offered short term credits with high interest rates that could only be used by a small group of higher income families (Akcay, 2003, p. 50; Ozturk and Dogan, 2010). In fact, until recently there has not been a sound financial 
system that could mobilize tangible assets and monetary savings into the housing market so that both investors and homebuyers could take advantage of affordable loans. Thus, personal savings and real estate cooperatives (building society) were the key solution for the middle and high income class to handle the housing finance problem. Recent data show that 89 percent of homebuyers have not applied for institutional loans to finance their houses (Ozturk and Dogan, 2010, p. 141).

Turkish housing finance has been managed by the central government, financial institutions, social security organizations, cooperatives and local governments. However, these institutions were not able to provide long-term affordable home loans. First of all, there has not been a robust financial system that could arrange a deal between those who were willing to construct or buy a house by loans and those who wanted to utilize their savings by lending. Financial institutions with limited tangible assets have therefore focused on more profitable options such as business or personal loans. In this regard, private banks have just started offering home loans in 1990s (Ayan, 2011, p. 147).

In addition to such a weak financial market, public organizations have shown short-lived assistance in housing finance as their budget provided only limited funding pool. Besides the Real Estate Public Bank (Emlak Bankasi), social security institutions such as SSK (social security for employees) since 1950, OYAK (the Institution of Military Assitance) since 1963, and Bag-Kur (social security for self-employment) between 1976 and 1980 provided home loans to their members but no longer do so due to their limited revenue and other economic reasons such as inflation (Ozkan, 2009: Ayan, 2011). Table 3 shows the amount of housing units that were given loans by such public institutions. As such, their contribution to housing finance is very low, especially when 
we compare their portion with the number of total housing units which is now almost 15 million.

Table 3. Housing production financially assisted by public institutions

\begin{tabular}{|lcc|}
\hline Instutions & Terms of Home Loans & Number of Housing Units \\
\hline Real Estate Bank & $1944-2000$ & 90,915 \\
SSK (Employees) & $1962-1987$ & 233,289 \\
OYAK (Military) & $1963-1992$ & 55,248 \\
Ministry of Public Works & $1966-1988$ & 893,050 \\
Bag-Kur (Self-Employment) & $1975-1980$ & 7,412 \\
\hline
\end{tabular}

Source: Aydin (2003, p.85).

After the 2001 financial crisis in Turkey, many strict regulations have followed to maintain financial stability. As a result of that, sharp decreases in inflation and interest rates and adjustments in financial risk management have made the banks look more favorably on home loans as profitable investments. In the last decade, the proportion of home loans in total financial trust as well as the capacity of total monetary assets has dramatically increased. Between 2001 and 2010, the monetary volume of home loans increased from 352 million to 52,105 million TL $(1 \mathrm{TL}=\$ 1.44$ in 2001, $\$ 1.54$ in 2010). This increase was also supported by the Mortgage Law passed in 2007 (Ayan, 2011, pp.145-146).

In response to inadequate housing finance provision by both the public and private sectors, the Mass Housing Fund was formed in 1984 as a resource external to the 
central budget. To administer this fund, the Mass Housing Administration (TOKI) was established in the same year with a duty of providing resources to the fund, organizing land-use, giving loans to mass housing projects of the cooperatives. In 1980s, the fund with its provision of credit increased the productivity of housing cooperatives, and the number of housing cooperatives increased as well. Through the legal adjustments and inter-governmental partnerships in 2000 s, TOKI became the single responsible public body for mass housing provision in Turkey.

The basic goal in establishing the fund was to provide the required public support through revenues earmarked for this purpose and to provide the required services through an administration created for this purpose in order to meet the housing needs at the national scale and to achieve an orderly process of urban development...Since 1984, TOKI has been acting effectively in providing affordable housing for the low and middle-income groups through innovative financial mechanisms. It has provided housing loans to approximately 1.2 million housing units by the end of 2004 (Mass Housing Administration, 2010-2011).

At the end of 2001, the Mass Housing Fund was deactivated due to its ineffectiveness in providing loans to the housing cooperatives. By 2002, the real estate and monetary funds of the Real Estate Bank had been transferred to TOKI, increasing its financial power even more (Yuksel and Gokmen, 2008). Table 4 shows TOKI's partnerships with real estate investment trusts in accordance with the revenue empowerment endeavors as the amendment in Mass Housing Law as of 2004 involves "establishing real estate companies or participating in those that have already been established" (Mass Housing Administration, 2010-2011). TOKI's such roles in housing 
finance and its tremendous housing investments in the last decade indicate that Turkish Mass Housing Authority has entered the housing sector as a primary actor.

Table 4 The Mass Housing Administration (TOKI)'s partnerships

\begin{tabular}{|c|c|c|c|c|c|}
\hline $\begin{array}{l}\text { Company Name and } \\
\text { (Year of Establishment) }\end{array}$ & $\begin{array}{l}\text { TOKI' } \\
\text { s share } \\
(\%)\end{array}$ & $\begin{array}{l}\text { Capital } \\
\text { (in } \\
\text { millions } \\
-T L, \text { as } \\
\text { of 2007) }\end{array}$ & $\begin{array}{l}\text { Profit / } \\
\text { (Loss) }\end{array}$ & $\begin{array}{l}\text { Short- } \\
\text { term } \\
\text { Liabiliti } \\
\text { es (in } \\
\text { millions } \\
-\mathrm{TL} \text {, as } \\
\text { of 2007) }\end{array}$ & $\begin{array}{l}\text { Long- } \\
\text { term } \\
\text { Liabiliti } \\
\text { es (in } \\
\text { millions } \\
-T L, \text { as } \\
\text { of 2007) }\end{array}$ \\
\hline $\begin{array}{l}\text { Emlak Konut Real Estate } \\
\text { Investment Trust- REIT } \\
(2006)\end{array}$ & 39.0 & 649.1 & 946.6 & $2,826.6$ & 129.9 \\
\hline $\begin{array}{l}\text { Emlak Real Estate } \\
\text { Marketing, Construction, } \\
\text { Project Management and } \\
\text { Trading Co. Inc. (2001) }\end{array}$ & 49.0 & 65.0 & $(0.8)$ & 44.5 & 10.0 \\
\hline $\begin{array}{l}\text { Metropolitan } \\
\text { Municipality } \\
\text { Construction, Real Estate } \\
\text { and Project Co. Inc. } \\
(2004)\end{array}$ & 49.9 & 10.0 & - & 0.2 & - \\
\hline $\begin{array}{lrr}\text { Real Estate } & \text { Appraisal } \\
\text { Valuation } & \text { Co. } & \text { Inc. } \\
(1998) & & \\
\end{array}$ & 49.0 & 0.5 & - & 0.2 & - \\
\hline $\begin{array}{l}\text { Vakif Real } \\
\text { Investment Trust } \\
\text { Inc-REIT (2004) }\end{array}$ & 14.0 & 18.48 & 5.2 & 0.1 & 0.1 \\
\hline $\begin{array}{l}\text { Vakif Construction, } \\
\text { Restoration and Trade } \\
\text { Co. Inc.(2005) }\end{array}$ & 53.1 & 10.0 & 0.4 & 3.4 & 0.5 \\
\hline $\begin{array}{lr}\text { Bogazici } & \text { Housing } \\
\text { Services Administration } & \text { Management Trade. Inc. } \\
\end{array}$ & 1.0 & - & - & - & - \\
\hline
\end{tabular}

Source: Mass Housing Administration (2010-2011).

TOKI-directed housing projects still continue to supply thousands of housing units to different income groups. Such projects are completed either through contractor real estate companies that have better tenders or TOKI-real estate company partnerships 
in which the administration provides available lands. TOKI's revenue consists of real estate property sale and leasing, credit payoffs, and central budget grants (Ayan, 2011). Among these property sales, TOKI undertakes profitable housing or building investment especially for high income group and business organizations to increase TOKI's revenue so that other projects can be implemented and housing credits can be provided to middle and low income families. In order to give loans to a housing project, TOKI requires the following (Mass Housing Administration, 2010-2011);

- Housing unit area should not be larger than approximately 1600 square feet

- Requirements for individuals who will be given loans:

- $\quad$ Married parents and their adult children can benefit from the home loan only once.

- They should not already have owned a house or used (or still be using) a home loan.

- Projects that will not benefit from the credit are summer houses, lodges, and other projects in which their purpose is to provide a second house to homeowner families.

TOKI's home loan offer is roughly based on five to ten-year credit terms, and the interest rate is equivalent to the increase rate in public servants' wages. At the same time, the payoff to the real estate contractor is to be made in two years after the beginning of construction (Mass Housing Administration, 2010-2011). Such imbalance in payoff terms leads TOKI to consume other financial resources such as sales revenue of public lands or budgetary aids. This raises sharp critiques on the method that TOKI uses in managing the 
mass housing finance since public resources are unnecessarily wasted, and the contractors tend to build low quality housing for its price (Ayan, 2011).

In essential, TOKI's funding and strategies for resource improvement have aimed at minimizing the huge shortage in Turkish housing finance while providing middle and low income families an opportunity to benefit from affordable home loans. On the other hand, private financial institutions have started offering home loans in the last two decades but they could only be obtained by relatively better-off families because the Turkish economy had little monetary assets in total for credit purchases. Although the Turkish economy and financial system was stabilized in the last decade and the mortgage law passed in 2007, TOKI's housing finance system attracts most families because of its loans' relative affordability. Such intervention in both housing and financial market by Turkish government can be criticized by private business actors as it shrinks the banks' credit portfolio and lowers real estate prices by increasing the housing supply. In the end, middle and low income families are given the opportunity to own a house with an affordable home loan provided by government authorities. 


\section{CHAPTER IV}

\section{MASS HOUSING PROJECTS OF TOKI}

The Mass Housing Law was passed in response to fast urbanization and rising housing problems, a desire to invigorate the economy through housing sector, and the constitutional mandate in 1984. At the same time, Toplu Konut Fonu (Mass Housing Fund) and its administrative mechanism, Toplu Konut Idaresi (Mass Housing Administration, 2010-2011) was established for such purposes. In the first two decades of TOKI (1984 to 2004), the administration's policy was to provide fiscal subsidies to housing cooperatives that construct housing units in a mass scale for their beneficiaries. As such, 84 percent of TOKI-funded housing units (almost 1 million) were built by such cooperatives (Kara and Palabiyik, 2009, p. 6). However, through the retrenchment in funding, the share of housing cooperatives in total housing construction decreased from 35 percent in 1988 to 6 percent in 2009. As well, the mass housing loans' share in total housing costs shrunk from 80 percent in 1985 to under 15 percent at the end of $1990 \mathrm{~s}$. Such ineffectiveness of Mass Housing Fund has called for direct involvement of TOKI in housing production through its new resource improvement methods starting with legal arrangements in 2004 (Coban, 2012, p. 78). As such, the Mass Housing Administration has taken an active role in housing finance and production for the last decade as a third party between the real estate contractors and the beneficiaries. The main objectives of Mass Housing Administration are as follows (2010-2011); 
- Issuing bonds and any kind of stocks with or without state guarantee.

- $\quad$ Deciding upon receiving loans from foreign resources to be used for the expenditure relating to its scope of activity upon approval of the Undersecretariat of Treasury.

- Taking actions aimed at ensuring participation of the banks in financing housing; providing banks with credit to this end; and establishing procedures relevant to enforcement of this provision.

- Supporting the industry related to housing construction or those who are involved in this field.

Since the date of establishment of TOKI, the priorities through the context of the solutions of housing and urbanization problem have changed. In this framework, new functions were added to the Mass Housing Authority by a 2003 amendment:

- Establishing companies related with housing sector or participating in those that have already been established.

- Granting individual and mass housing loans; granting loans for projects intended for improvement of rural architecture, transformation of squatter areas, preservation and restoration of historical and regional architecture; and making interest subsidies for all such loans, where deemed necessary.

- Developing projects both in Turkey and abroad directly or through an agency. 
- Implementing or appointing others to implement profit-oriented projects to ensure sources to the benefit of the administration.

- $\quad$ Building, promoting and supporting construction of housing units as well as social facilities and infrastructure in locations where disasters take place, if considered necessary.

In parallel, the Mass Housing Law Amendment in 2004 empowered the administration's authority:

- $\quad$ TOKI is authorized to realize all kinds and scales of development plans, to have made all these type of plans and to alter these plans in areas determined as the mass housing settlement regions.

- TOKI is authorized to expropriate all buildings on or inside the lands and areas owned by real and legal entities, within the framework of its duties under law.

- $\quad$ TOKI is authorized to operate transformations of squatter areas

These functions and authorities given by the amendments hand in hand with its affiliation with Prime Ministery have turned Mass Housing Administration into a sort of "national municipality" and "real estate corporation" that has relatively more power and comparative advantages than other actors in housing sector.

The first part of the mass housing period (1984 to 2002) involved highly effective housing cooperatives whose construction costs were subsidized through government housing credits, whereas the second half (2002 to 2012) characterized direct and active 
involvement of the mass housing authority in housing production, and urban renewal policies became a priority of the Mass Housing Administration. Between 1984 and 2003, TOKI has produced only 43,145 housing units besides the hundred thousands of creditsubsidized housing units by housing cooperatives. Through legal empowerments and active involvement after 2002, TOKI has constructed 559,705 mass housing units in 2,470 construction areas, 81 provinces, and 800 counties. This number is roughly equivalent to 22 cities with each having 100,000 populations. Total investment costs of this mass housing construction and social facilities are approximately 48 billion TL (almost $\$ 30$ billion), and they were implemented through 3,793 different contracts. Based on TOKI's activity report, Table 5 shows the distribution of project implementation in different categories.

Table 5. TOKI project implementations (2003 to 2012)

\begin{tabular}{|l|r|r|}
\hline Mass Housing Attributes & Number of Housing Units & Percentage \% \\
\hline Middle Income Housing & 221,653 & 39.6 \\
\hline Low Income Housing & 143,065 & 25.56 \\
\hline $\begin{array}{l}\text { Urban Renewal (Squatter } \\
\text { Transformation) Housing }\end{array}$ & 68,167 & 12.18 \\
\hline Disaster Housing & 37,420 & 6.69 \\
\hline Agriculture Housing & 5,584 & $\mathbf{8 5 . 0 2}$ \\
\hline Total Social Housing & $\mathbf{4 7 5 , 8 8 9}$ & $\mathbf{1 4 . 9 8}$ \\
\hline $\begin{array}{l}\text { Total Resource Improvement } \\
\text { Housing Investments (Profit- } \\
\text { Oriented) }\end{array}$ & $\mathbf{8 3 , 8 1 6}$ & $\mathbf{1 0 0 . 0}$ \\
\hline $\begin{array}{l}\text { TOTAL (without pending } \\
\text { projects) }\end{array}$ & $\mathbf{5 5 9 , 7 0 5}$ & \\
\hline
\end{tabular}

Source: Mass Housing Administration (2010-2011) 
Table 6 Social facilities constructed by TOKI between 2003 and 2012

\begin{tabular}{|l|l|l|l|}
\hline Social Facilities & Total & Social Facilities & Total \\
\hline Schools & 859 & Mosques & 448 \\
\hline Sport centers & 888 & Libraries & 41 \\
\hline Dormitories - hostels & 114 & $\begin{array}{l}\text { Social service } \\
\text { facilities }\end{array}$ & 27 \\
\hline $\begin{array}{l}\text { Primary healthcare } \\
\text { centers }\end{array}$ & 91 & $\begin{array}{l}\text { Senior care } \\
\text { facilities }\end{array}$ & 20 \\
\hline Hospitals & 199 & $\begin{array}{l}\text { Government } \\
\text { buildings }\end{array}$ & 68 \\
\hline Trade centers & 471 & Stadiums & 6 \\
\hline
\end{tabular}

Source: Mass Housing Administration (2010-2011)

TOKI has also built numerous social facilities in accordance with mass housing projects (see Table 6). In fact, TOKI defines mass housing projects not only as dwelling sites for families but also as social living places where the homeowners can benefit from social services located in the same area, such as religious, healthcare, educational, and other facilities.

On the other hand, TOKI recognizes that squatter housing problems cannot be resolved solely by local authorities. Thus, urban renewal projects have come to be seen as a part of state policy in which TOKI was authorized to manage squatter transformation and renewal attempts. As such, 12 percent of mass housing projects was to transform slum areas into a liveable decent housing sites in major Turkish cities.

Unresponsiveness of city governments to the rapid increase in housing demands has caused an undesirable settlement pattern in urban areas that threatens the cities' identity and socio-economic conditions. Not only squatter settlements but 
also poorly constructed old houses especially in cities having disaster risks became a chronic urban problem in Turkey. Today, many houses that were built on inconvenient lands, with poor quality materials, lacking essential civil engineering and modern construction methods still threaten the households' life and damage the city landscape (Mass Housing Administration, 2010-2011).

Urban renewal has recently been extended to the high disaster risk areas other than squatter towns (see Figure 3). Poorly constructed old dwellings standing on major earthquake faults are now subject to the renewal process through the Regulation of Transformation of Disaster Risk Areas passed in May 2012. By this regulation, many old dwellings will be assessed by a committee in terms of whether they contain a high earthquake risk. The ones that are determined risky will be demolished and their households will be given housing subsidies until they are settled in their new houses. Also, the estimated value of transformed houses will be assessed and deducted from the construction costs of new housing settlements where the households begin to settle in.

This extended urban renewal was encouraged by the scientific projection of the possible outcome of a major earthquake in Istanbul, with a population of almost 17 million located just north of the major earthquake fault (North-Anatolia). During his visit to the city of Van right after a major earthquake hit in 2011, the prime minister stated that "this disaster-based urban renewal process will be realized even if it takes losing the election". Initially, thousands of high disaster risk dwellings in 35 provinces have begun to be demolished (Koc and Inan, 2012). 
Figure 3. Urban renewal examples by TOKI

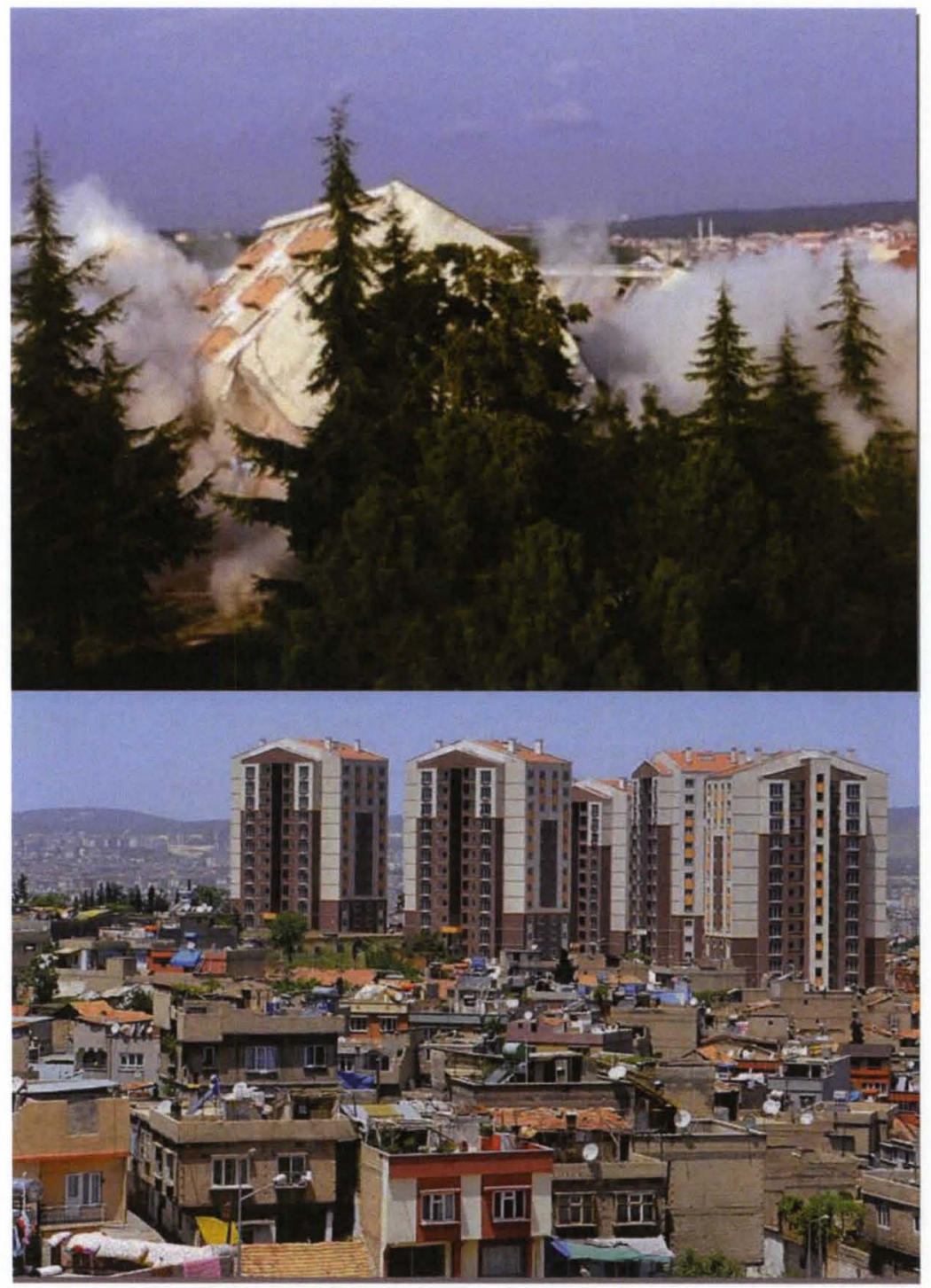

Source: Anadolu Agency

During 20 years of its existence, TOKI has been instrumental in providing affordable housing for the poor through innovative financial mechanisms. Being the foremost government agency concerned with housing in Turkey, TOKI has accumulated considerable knowledge and experience in implementing different modes of housing finance. For its mass housing projects produced on its own land, TOKI has the target group of low and middle income families, who are not able to own a housing unit within 
the existing market conditions in Turkey. As a governmental agency, TOKI has adopted a model for providing mortgage loans. Through this method, the selling of the housing units takes place before the construction period. The cost of the houses is determined after receiving the quotations of the contractors. The sales price of each housing unit is then finalized, accounting for the cost of land, off-site and plot infrastructure, social facilities, and technical services. Roughly 10 to 40 percent of the cost of the house is initially collected as a down payment, depending on the affordibility of the target population and the rest of the cost is spread over a maturity ranging from 75 to 240 months (Mass Housing Administration, 2010-2011).

Facing a critical shortage of 2.5 million units over the next five years, TOKI is seeking to build between five and ten percent Turkey's housing needs. To fulfill this mission, the administration has created financial subsidiaries and affiliates so that home loans and interest subvention could be more possible. TOKI's vision for the future strives to (Mass Housing Administration, 2010-2011):

- Create a model framework for affordable quality housing,

- $\quad$ Prevent real estate speculation that might use low-quality materials in the construction of low-margin housing,

- $\quad$ Produce housing for regions in Turkey where the private sector is not active,

- Offer low and middle income groups an opportunity to finance their own houses,

- Offer rural housing opportunities that decrease the pressure on the migration to urban areas, 
- Collaborate with local authorities to create urban renewal projects and

- $\quad$ Create financial opportunities to finance social housing projects such as innovative income-sharing projects with the private sector.

Figure 4. A mass housing project for low income population

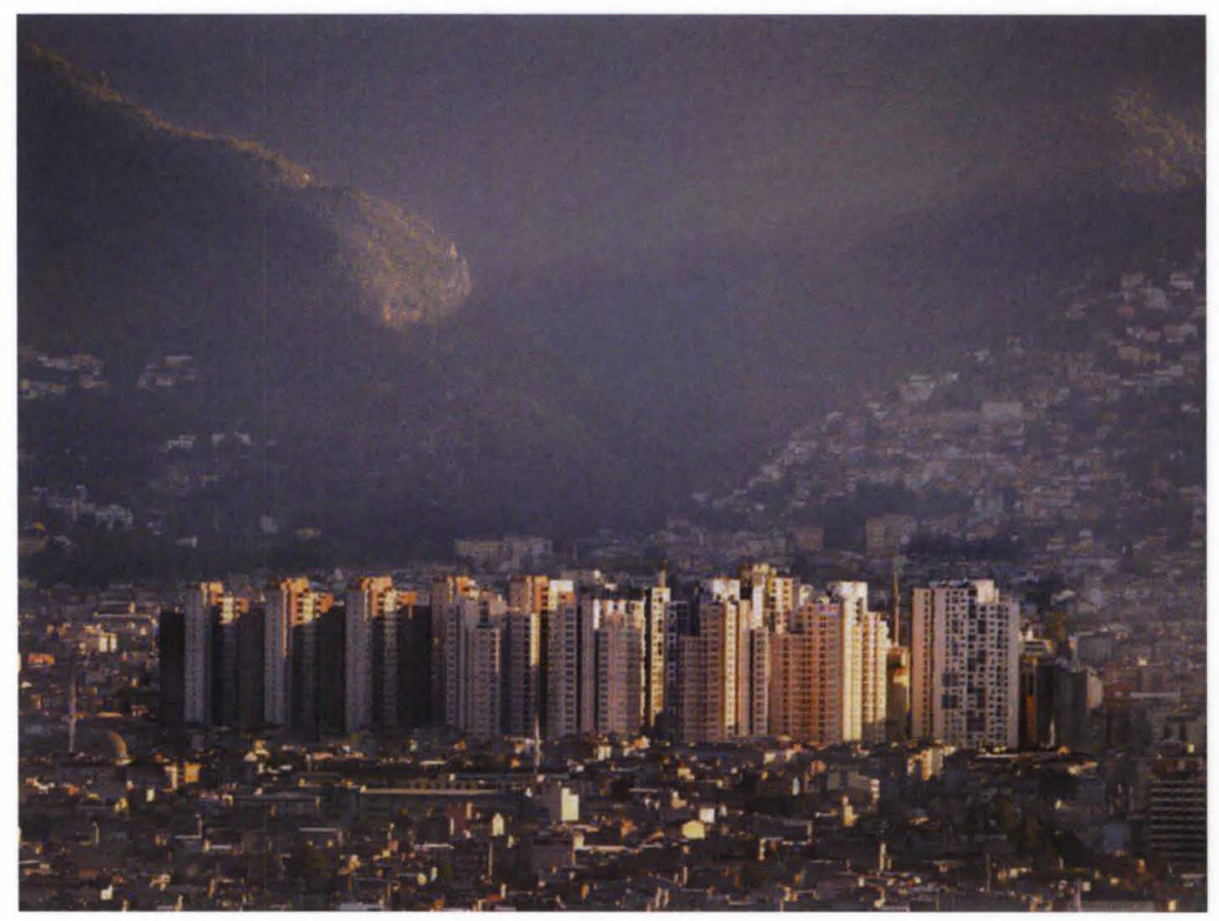

Source: Photo taken by Erdal Yavuzak

The extra revenue generated from for-profit projects is essential for the financing of TOKI's social housing projects. Filling the gap between short-term capital outlay for construction and long-term receivables from mortgage payments, the revenue sharing model generates crucial capital for low- and middle-income housing projects (see Figure 5). 
Figure 5 An example of for-profit projects

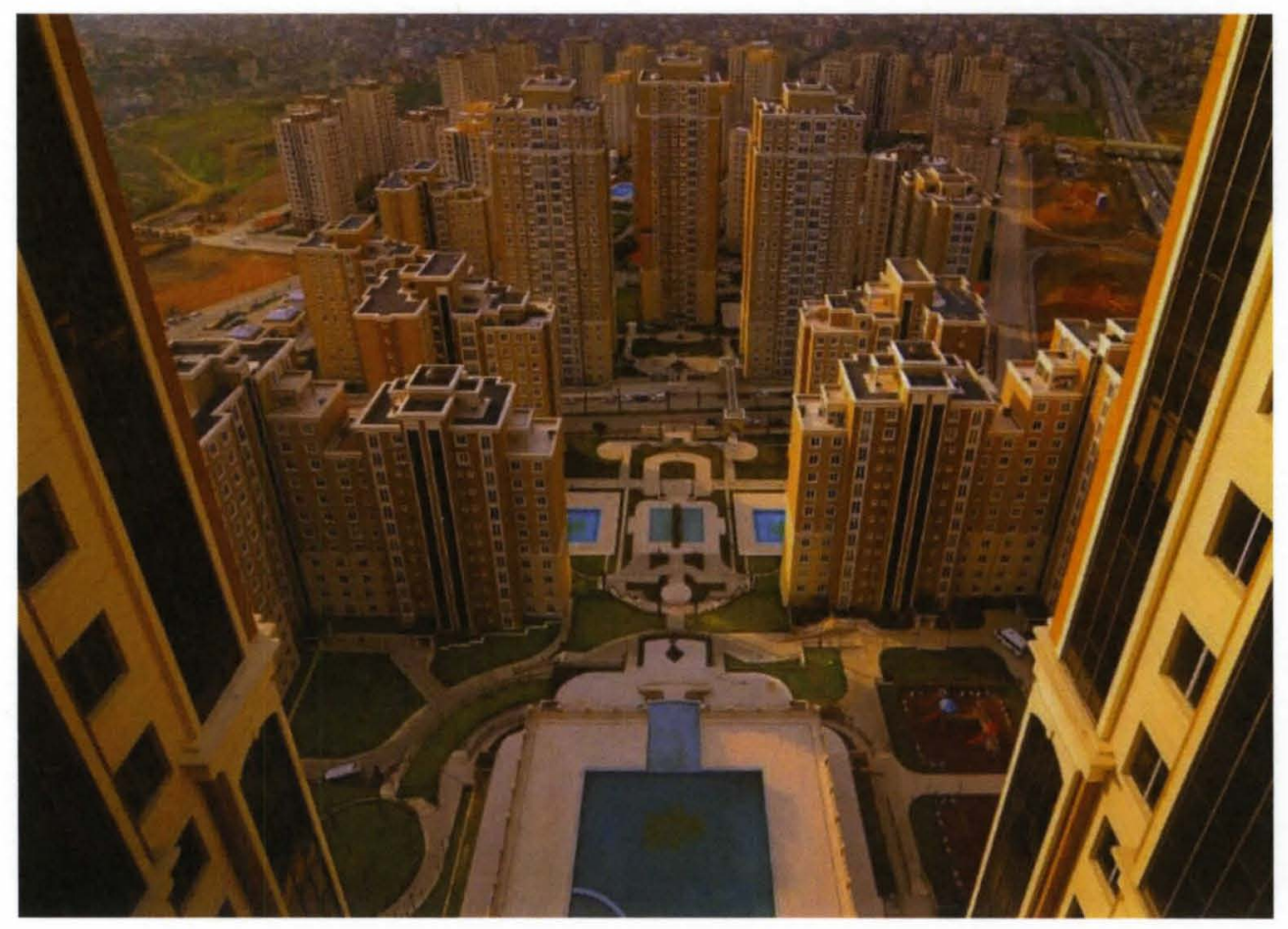

Source: Photo taken by Mustafa Gezer.

Overall, TOKI as a government entity has become the largest housing producer in the last ten years. TOKI with its projects and methods are awarded in international milieu such as the Best International Real Estate Project at the Barcelona Meeting Point Conference in 2007 and the International Award for Entrepreneurship in Real Estate and Housing Development sponsored by Expo Italy Real Estate.

Nevertheless, TOKI's methods and practices receive substantial criticism from scholars and civil associations. While it is commonly agreed that TOKI helps narrowing the housing gap, the arguments against the mass housing authority is built upon the 
methods used in its housing provision. Those arguments will be explored in more detail in the next chapter.

Figure 6 TOKI construction zone

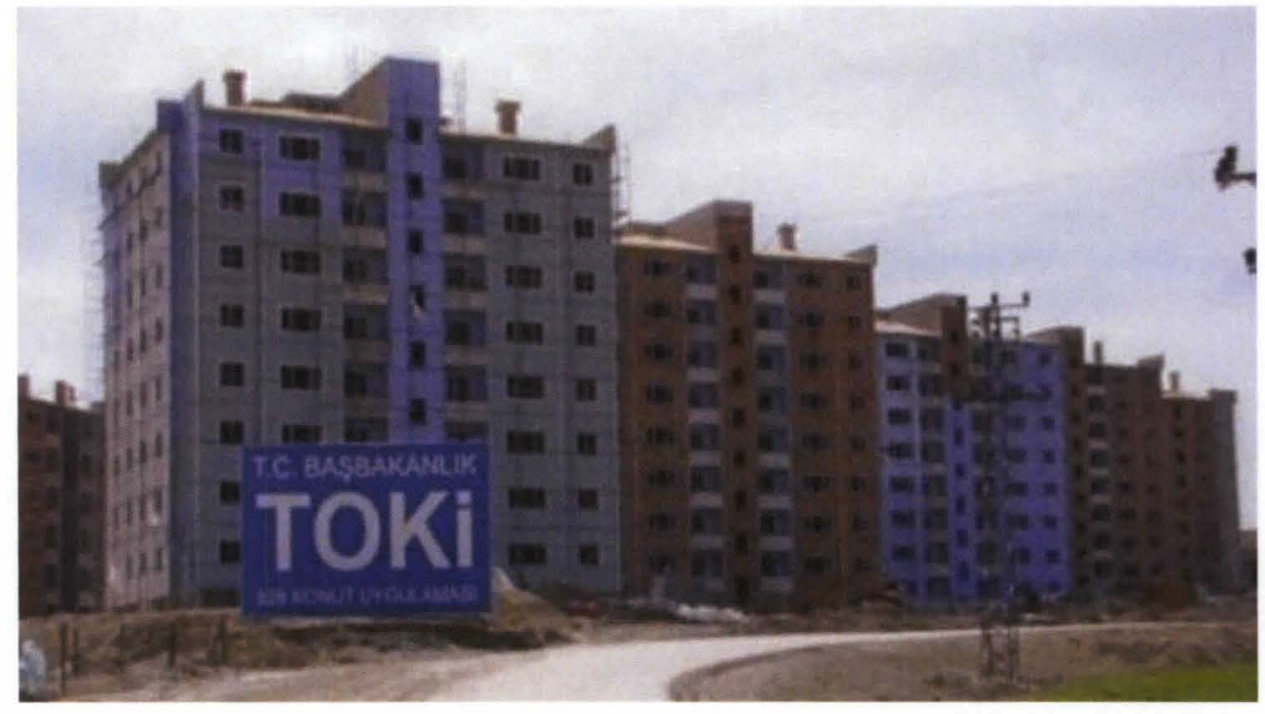

Source: Anadolu Agency. 


\section{CHAPTER V}

\section{LITERATURE REVIEW ON MASS HOUSING PRACTICES IN THE LAST}

\section{DECADE}

Mass housing practices by direct involvement of government authorities are still young in Turkish housing provision. For the last ten years, Mass Housing Administration (TOKI) that was established in 1980 s to provide housing loans only has extended its role and taken a position of single authority in meeting the housing needs. Although it is considered that the quantitative objectives of the Authority are mostly met (Yuksel and Gokmen, 2008), there are some critiques on the methods used by TOKI in its mass housing provision, and on their outcomes.

Among the criticized aspects of TOKI are (Yuksel and Gokmen, 2008):

- TOKI is the only authority concerned with selling urban land, making decisions on planning and determining the value of lands. Hence it is a kind of government supported monopoly in the housing sector (Geray, 2009).

- TOKI has rights and authority of a financial institution among other finance offices and banks.

- TOKI has extended power on city planning and tax exemption.

- The government makes it easier to sell public lands for the use of TOKI (Yuksel and Gokmen, 2008). 
Recent mass housing finance is mostly met through the sales of public lands in which every citizen has a claim. When we consider that the majority of mass housing beneficiaries are middle income families, mass housing practices with such financial methods raises an ethical question in terms of whether public resources are equally allocated (Ayan, 2011). As such, in 2004, all duties and authority of the Urban Land Office were transferred to TOKI. Based on this legal arrangement, 64.5 million square meters of land have been passed on to TOKI's portfolio (Gokmen and Ozsoy, 2008).

Some criticisms claim that TOKI transfers valuable urban land to construction firms at low prices, and that there is no sufficient control on these land sales (Tuna, 2009).

TOKI declared that it has built homes for low-income groups. It gives 45 to 60 square meter flats to these families, but they are generally big families, and the flats do not fit these families. It is asserted that the authority does not consider the saving capacities of poor families (Tuna, 2009). The housing problem based on over-crowding in squatter dwellings due to large family size was not actually resolved by recent mass housing policies, instead, the problem was relocated into apartment buildings. Also, the squatter town populations who settle in mass housing projects tend to leave such places either by selling or leasing their dwellings since they maintain their cultural habits and lifestyle in neighborhoods similar to their older places and use the mass housing unit as a commodity (Coban, 2012).

Some criticize that TOKI is not very successful in organizing housing demands. In some cities like Ardahan, Bitlis, Erzurum and Şanliurfa, TOKI could not sell 1,515 
housing units out of 1,625 built (Tuna, 2009). Turkish Government Control Institution has submitted a report about TOKI projects. In this report, they have highlighted the fact that TOKI has built housing all over Turkey, but that it does not consider economic conditions, housing needs, or possible housing demands of settlement areas; TOKI did not undertake feasibility analysis in chosen areas (Tuna, 2009). "TOKI's use of the same formwork producing the same house plan types in all cities and in the same fashion indicates that the qualitative and quantitative user needs targeted have not been properly analyzed and that is a problem" (Tomruk, 2009). For instance, in Samsun Province, TOKI housing that was located in the river plain in 2010 was flooded. The disaster left nine casualties in that area (Sandikci, 2012).

Economically TOKI is now the largest real estate investor in the country. The organization's huge financial resources including public goods are being transferred to real estate companies that are generally close to the ruling party. So, TOKI maintains its high status in the real estate industry while its political purposes are also realized (Antalya Chamber of Architecture, 2008).

Some criticize the fact that the housing gap is only being met by TOKI as a monopoly in the housing market (Yuksel and Gokmen, 2008). Various trade organizations associated with Union of Chambers of Turkish Engineers and Architects criticize the housing practices of TOKI in a similar way. A press statement of Bursa Chambers of Engineers and Architects declared that TOKI apparently harms the development of the real estate sector by using public resources and availabilities for the production of middle- and higher-income housing. TOKI's exemption from governmental fees and bureaucratic procedures also forces other real estate actors out of the market. 
The organization further states that TOKI's mass housing projects are not credible since their processes of planning, implementation and controlling have multiple problems (Gur, 2012).

TOKI has conducted a nationwide survey via Pollmark R\&D Company to determine the customer satisfaction. A total of 85 different mass housing projects in 26 provinces were selected as a study area, and a randomly-selected sample of 2,346 households were interviewed using personal in-home survey techniques.

The results show that the great majority of the respondents were highly satisfied with their housing and 81 percent would recommend their housing to other families. The survey revealed that only 65 percent of TOKI homebuyers actually reside in their houses while the rest of them chose to rent their properties to other people.

Another finding of Pollmark Survey shows that 34.2 percent of TOKI households' net monthly earnings are between 501-1000 TL and 62.7 of those are under $1500 \mathrm{TL}$. In the same year (2010), the Turkish Census Bureau determined the poverty line for fourperson households as 2,827 TL (monthly). It is actually seen that the most TOKI beneficiaries are low-income families.

One of the major criticisms of the mass-housing projects in urban areas is related to those built at the periphery for low-income people; their far distance from their work places and social networks may turn out to be a problem and the units may even be vacated by their dwellers (Kumkale, 2009). Tekeli (2008, pp. 55-56) noticed that since TOKI has built large numbers of housing units, they tended to select vacant lands at urban edges without taking into account zoning plans. The result is basically 10 or 20 thousand housing unit clusters that are disconnected from urban life. In the Pollmark 
survey, only 55 percent of the households consider that the place selection for mass housing settlement was convenient.

In some cases, the relocatees who are the beneficiaries of mass housing projects were given land or a house at the urban periphery rather than at the original renewal sites located in central cities (Uzun, 2005, pp. 206-213). The relocation of squatter town populations to urban peripheries under the name of urban renewal is generally followed by large business investments into the renewal sites as the vacated lands are usually sold to business investors. This tendency indicates the fact that urban gentrification process becomes a central pattern of mass housing projects in Turkey (Coban, 2012).

Distinguished urban scholar Prof. Rusen Keles was interviewed about TOKI housing practices in 2012. Keles considers that TOKI directed urban renewal attempts are more selective on the exchange value of possible renewal sites. On the other hand, Keles states that there is a dual urban planning structure at Turkish cities in that TOKI's housing projects are usually exempt from the exclusive urban planning of local governments. TOKI projects are uniformly applied to all urban areas by a central government organization without effectively cooperating with local actors in urban planning matters (Tavsanoglu, 2012).

Those who built squatter houses after the zoning amnesty in 1985 are not considered as beneficiaries of TOKI's urban renewal practices so they usually lost their current dwellings and did not benefit from the mass housing option. Such groups are becoming more organized recently to make their demands heard (Meric, 2010).

Also, a remarkable number of beneficiaries cannot afford the mortgage payment so that they either have to sell their houses or be faced with the foreclosure (Baysal, 
2010; Gümüş, 2010). According to 2000 census data, the number of households in Turkey is a few more than 15 million, 68 percent of whom are homeowners while the rest consists of tenants, lodgment dwellers, and so forth. The share of homeowners in total households decreased 8 percent in seven years according to 2007 census data (TUIK). According to the Pollmark survey, 70 percent of the households stated that they had difficulties paying off the mortgage due to their low income level.

Although the quantitative success of TOKI in housing production cannot be denied, the qualitative aspects of mass housing production are mostly overlooked. This only encourages people's investments in real estate more than providing residences for those who do not have one as many of mass housing units are either for sale or rent in the market (Yuksel and Gokmen, 2008). In parallel, only 20 percent of households used home loans whereas 80 percent bought their houses with their personal savings according to Pollmark Survey.

Another survey was conducted with a sample of 364 households in TOKI projects in the city of Bursa. In analyzing the reason of preference, the majority (70.9 percent) prefer those housings because of economic reasons. Other reasons of preference involve family reasons (10.4 percent), the availability of social facilities ( 7.4 percent), proximity to work (5.5 percent), physical features of housing land and construction (4.7 percent), and security ( 1.1 percent). 68 percent of the respondents stated that they feel satisfied with living in TOKI housings (Gur and Dostoglu, 2010, pp. 148-150).

The most prevalent critique about social housing projects built by TOKI is poor construction quality (Ayan, 2011). Many mass housing contracts can be taken by real estate companies which have little capital base to handle this kind of project. In addition, 
the agreement between TOKI and real estate contractors does not necessarily include the construction quality and entail effective sanctions in order to monitor due process. Through such ineffectiveness of the contracts, real estate contractors can easily reduce the construction costs (labor and material) and, therefore, the quality. To receive their progress payments, they also build the housing projects so fast without concern about whether the housing quality standards were fully met (Ayan, 2011).

In fact, there have been no specific qualitative goals set by TOKI in its housing provision. Due to quick mass production, the buildings have little flexibility in design and turn out to be monotype entities. In particularly, TOKI does not take account of local and climate differences when mass housing projects are realized throughout the country (Yuksel and Gokmen, 2008).

There are many complaints about the basic elements of housing structure. As such, according to the Pollmark Survey, only 45 percent of the households were satisfied with the quality of housing materials and the construction even though the level of satisfaction with general and environmental attributes of the housing was about 70 percent.

TOKI's social housing projects are also criticized in terms of their architecture. Such projects are monotype and anonymous mass productions that hardly pay attention to geographic features and cultural aspects of a region changing city to city and do not meet the standards of both modern and traditional architectural perspectives (Gür, 2012).

Almost all critiques emphasize that TOKI's practices focus only on narrowing the housing gap by producing housing units at a mass level. By doing so, the qualitative aspects of these buildings are usually taken as given, and the administration does not pay 
attention to the geographical features of a region when applying its housing provision throughout the country. Its excessive use of public lands and monopolistic role in real estate market also receive critiques from scholars and civil organizations. 


\section{CHAPTER VI}

\section{HYPOTHESIS}

Most of the literature concerning housing provision of TOKI lacks enough empirical analysis. Such tendency is actually because there is no exclusive data being publicly released by government authorities. However, Turkish Statistics Institution's database can be used to extract some indicators at the province level, although the institution does not periodically collect all informative data to be used for time-series analysis and provide it within block-level units for some analysis such as housing study.

In an attempt to fill this empirical gap, the research questions of this study focus on the general beliefs discussed in the literature review concerning TOKI practices. In general, this study first investigates what factors are determinant on TOKI's housing provision and secondly seeks to find out whether it has important socio-economic implications in parallel with the arguments raised in the Turkish housing literature.

The most apparent criticism on TOKI mass housing provision is that the administration overly utilizes available public lands in financing its housing production. On the other hand, TOKI's vision is presented as to fill the housing gap by giving home ownership opportunities to those who do not own homes. In this manner, this study tests whether available public lands and the high tenancy rate in Turkish provinces influence the authority's housing provision. In addition, to better fill the housing gap, TOKI is 
expected to respond to population change. The provinces whose population increases will obviously need more housing units. Finally, it will also be tested that central governments' accelerated mass housing production was nothing more than payback for political support in the election (2002). Radical changes in mass housing provision were made when the Justice and Development Party came to power and it was the starting point for the increasing number of mass housing projects in the last decade.

The second phase of this study's hypothesis focuses on the expected implications of TOKI's methods on mass housing production. Through radical reforms and gained comparative advantage, TOKI has become a single authority and effective monopoly in most of the housing provision in Turkey. Providing housing supply for middle and higher income families to make profit in order to finance its subsidies to lower income households is expected to result the withdrawal of private actors from the housing market. Other critiques concentrate on the claim that TOKI consumes an excessive amount of land for its projects. When this issue is combined with the argument that the administration exploits available public lands, the importance of its land use considerably becomes much greater.

The investigation of this study also seeks for whether mass housing provision attracts people from other locations and increases the migration level toward the provinces where it is more prevalent. Such nationwide government subsidies to housing issues give many citizens a chance to own a house with affordable payment options. Thus, the more available mass housing units a province has could make it more attractive for people who could not take advantage of such an opportunity in their current provinces. 
Although it is not mentioned by scholars, there is the common belief that the current administration has increased its political support partly due to their intense efforts in mass housing provision. After the first success of the Justice and Development Party in the 2002 election, the ruling administration gained more support in the following elections in 2007 and 2011. So, the political outcome of mass housing projects will also be tested.

Based on the arguments described above, it is hypothesized that:

a) High rates of rental occupancy, available public lands, high population increase, and political support are the motivating factors on TOKI's mass housing provision.

b) TOKI's policies and practices lead to more political support, less private initiatives in the real estate sector, more land consumption, and increase in net migration. 


\section{CHAPTER VII}

\section{METHODS AND DATA}

Multiple linear regression analysis will be used to assess possible causal factors behind the rapid increase of mass housing production in the last decade, and also the measure of Pearson correlation will be utilized to find the link between the mass housing provision and its conceived outcomes. Common trends to test the impact of current mass housing units on families are usually based upon the consumer satisfaction surveys conducted either by TOKI or urban scholars. Although the survey method is very helpful to assess the first-hand impact of the mass housing units on its beneficiaries, it gives no clue about the general implications or driving causal factors of the housing provision as the individuals by themselves cannot answer how much land space is consumed or which factors are determinant during the process. Thus, besides the survey method in housing evaluation, it is necessary to utilize available databases to answer such general questions.

The models of this study are twofold. One is to test the determinants of implementing mass housing production. The second model aims to find out what outcomes TOKI produces in its efforts to subsidize housing production at a mass level. Therefore, to test the first hypothesis, mass housing provision is modeled as function of population increase, available public lands, rental occupancy rates, and the political support for the ruling administration. As controlling factors, the impact of earthquakes with the magnitude higher than 6.0 in recent decades, and the metropolitan cities will be 
added to the model. In the second phase, the mass housing units per thousand is also modeled as the causal factor of real estate company shutdowns, more land space consumed for housing, higher net migration to more subsidized provinces, and more political support to the ruling administration.

Model I: Mass housing units by TOKI per $1000=\beta$ (Population Change between 2000 and 2011, The Share of Public Lands in Total, 2002 Election Results for the Ruling Party, The Rate of Tenancy in Total Households, The Earthquakes between 1980 and 2003, Metropolitan Areas) $+\mathrm{e}$

Model II: (Net Migration in 2011, The Rate of Closed Real Estate Companies, Total Land Use for Housing, 2007 and 2011 Average Election Results for the Ruling Party) $=p($ Mass housing units by TOKI per 1000) $+e$

Datasets are obtained mainly from Turkish Statistical Institute (TUIK) and Mass Housing Administration (TOKI) as they periodically disseminate databases concerning various subject matters. Although most general indicators are publicly reported by the institution, more exclusive data collection and dissemination via more decentralized unit of analysis selection is needed to increase empirical analysis on both national and local level issues in Turkey. Thus, the data collection of this study is limited to the availability of information provided by Turkish Statistical Institute and Mass Housing Administration (TOKI).

\section{$\underline{\text { Units of Analysis }}$}

The units of analysis of this thesis are Turkish provinces. There are currently 81 provinces in Turkey; those are the highest local branches of central government. As the 
characteristic of unitary system, 81 provinces of Turkey ensure that the will of central government (the cabinet) is applied to each local place. According to Turkish Constitution, Turkish central government is divided into provinces based on the geographical features, economic conditions, and the necessities of the public services. The administrative heads of provinces are located in urban areas together with municipal governments.

The Turkish Statistical Institution disseminates its collected database based on different administrative units but it does not provide block level information such as census tracts. Among the published datasets, provinces are the best administrative unit to evaluate mass housing provision since most of the applications are located in urban areas which are also the centers of province administration.

\section{Variables}

Mass Housing Units by TOKI per 1000

Mass Housing Administration in its official website publishes the number of both completed and in-process mass housing units once the project is initiated in the administrative borders of provinces. Based on the number of mass housing units issued in each province, the level of mass housing provision by 2010 is obtained through the ratio of housing units to the provincial population. It is simply calculated as the number of mass housing units divided by provincial population and then multiplied by 1000 . 


\section{Population Change between 2000 and 2011}

The population census has been conducted regularly by the Turkish Statistical Institution since 1927. Up to the 1990s, the census was carried out in every five years but it became decennial afterward. In recent years, the census methods have changed, and a new system called address-based census was adopted to gather demographic and socioeconomic information more effectively. As an indicator, the percentage change between 2000 and 2011 censuses will be used in this study to reveal if the mass housing initiatives comply with the demographic changes in local areas.

\section{The Share of Public Lands in Total Areas}

The Turkish government owns significant amounts of property including lands, buildings, green areas, forests, historical reservations, and so forth. Their total areas were calculated by National Property Management to determine the land areas of the state's property ownership in every province. The ratio of public lands to total areas of the provinces is calculated simply by dividing the public lands by the total surface of the provincial areas excluding lakes and rivers.

\section{Rental Occupancy Rates}

The statistics of households' ownership status is available only in the 2000 census. This indicator is obtained from the number of tenants divided by the total number of households. Unavailability of this statistic for recent years limits this study's ability to track possible changes in ownership status due to the mass housing projects. The only available data regarding ownership status of households was released as a sectoral share of gross domestic product in nationwide calculations that do not specify local units. 


\section{Net Migration Change}

The numeric difference between population loss and gains to and from other provinces or foreign countries is defined as net migration. It is calculated by Turkish Statistical Institution in every census year. Net migration data for each province calculated in 2000 and 2011 is used in this study as one of the explanatory variables. To measure the percentage change of net migration in two different years, the formula being used is:

(net migration 2011 - net migration 2000) / net migration 2000 |

The Rate of Closed Real Estate Companies

Turkish Statistical Institute also tracks the number of existing, closed or newly opened business companies in all sectors. As part of this study's analysis, the ratio of closed business companies and cooperatives associated with housing sector is calculated as the number of real-estate company and cooperative shutdowns between 2002 and 2009 is divided by the total number of housing sector companies in 2002 for a given province.

\section{Total Land Use for Housing}

Land areas consumed for housing constructions between 2002 and 2010 will be used to discover how far the mass housing settlements at the same period influence the land use for housing across the provinces. TOKI in its activity reports does not release the land area of its projects. The most available way to assess this issue is to find possible links between total land areas for housing in each province and the level of mass housing provision at the same period. 
General Election Results for the Ruling Administration (in 2002, 2007, and 2011)

National Parliamentarian Elections in Turkey are conducted every four years (was every five years before the 2007 referendum) by a system based on proportional representation. In this study, the political support of each province to the ruling administration is determined by adopting the percentage of votes in a given province that went to the current administration. The results are utilized to find out whether the mass housing provision is selective on political support in the 2002 election and increase that support in the same direction at the following elections of 2007 and 2011. While the first variable involves 2002 election results, the second is obtained by taking simple average of the more recent elections.

\section{Earthquake (between 1980 and 2003)}

Turkey has several large and small earthquake faults. Throughout the history, there have been many destructive earthquakes affecting Turkish cities. Since most buildings in Turkey do not meet the ideal standards of resistance for natural disasters, they either collapsed or be damaged when a major earthquake hits. Such destructive earthquakes usually cause a significant level of housing paucity. Thus, the major earthquakes that hit the Turkish provinces in the period of 1980 and 2003 with a magnitude higher than 6.0 is added to the regression model as a dummy variable in order to control the effect of these earthquakes on the mass housing provision.

\section{Metropolitan Areas}

Among the 81 provincial centers in Turkey, 16 of them are metropolitan municipalities. Due to their large populations, these metropolitan municipalities have 
relatively more mass housing units in total. Therefore, this study controls the effect of metropolitan areas by adding a dummy variable into the regression model.

Table 7. Descriptive statistics

\begin{tabular}{lccccc}
\hline Variable & N & Minimum & Maximum & Mean & Std Deviation \\
\hline Housing unit by TOKI (per 1000 persons) & 81 & 0.38 & 50 & 6.63 & 0.77 \\
Population change (2000-2011) & 81 & -0.34 & 0.36 & 0.006 & 0.01 \\
The ratio of public lands in total & 81 & 0.0003 & 0.75 & 0.27 & 0.01 \\
General election results for the ruling party (2002) & 81 & 0.06 & 0.84 & 0.33 & 0.01 \\
The ratio of tenancy in total households & 81 & 0.09 & 0.35 & 0.19 & 0.005 \\
Net migration change (2000-2011) & 81 & -9.18 & 3.75 & 0.11 & 0.17 \\
The ratio of closed real estate companies & 81 & 0.006 & 2.05 & 0.28 & 0.03 \\
Total land use for housing (square kilometer) & 81 & 0.05 & 79.5 & 5.72 & 1.19 \\
General election average results (for 2007 and 2011) & 81 & 0.14 & 0.69 & 0.49 & 0.01 \\
Earthquake (1980-2003) & 81 & 0 & $1(8)$ & 0.09 & 0.03 \\
Metropolitan areas (by 2009) & 81 & 0 & $1(16)$ & 0.19 & 0.04
\end{tabular}

Table 7 shows the descriptive statistics of variables. Provinces with higher number of mass housing units per thousand are generally located in the mid-parts of Turkey. Konya (50), Kocaeli (31), Sivas (19), Kirikkale (18), Kutahya (17), and Erzincan (15) are among the provinces where per capita housing unit is at the high level. Kocaeli, which is located in the North-West coast, received relatively more housing provision since the massive earthquake in 1999 hit the region by leaving thousands of buildings demolished. On the other hand, most of the coastal provinces such as Sinop (1.1), Aydin (1.3), Mugla (1.3), Hatay (1.8), and Mersin (2.3) contain less per capita housing unit by TOKI (see Figure 7). 
As first model attempts to find out what possible determinants influence the mass housing provision, the variables of rental occupancy rate and population change are examined as demographic factors. In 2000 , the provinces with high tenancy rates are primarily Izmir (35 percent), Ankara (31 percent), Konya (27 percent), Bursa (26 percent), K.Maras (27 percent), and Gaziantep (26 percent). In general, high tenancy rate is observed in areas with large populations (see Figure 10). On the other hand, high population increase between 2000 and 2011 occurs primarily in the west, mid-south, and southeast regions of Turkey. Exceptionally, the southeast region has the highest birth rate in comparison to other regions (see Figure 8).

The ruling administration (Justice and Development Party) gained most of its political support from the north and middle of the country as the coastal provinces together with eastern cities gave little support. More than half of the electorates in Siirt (84 percent), Kirikkale (74 percent), Erzurum, Kayseri, Konya (54 percent), K.Maras (53 percent), Duzce (52 percent), and Yozgat (51 percent) provinces voted for the political actors of recent mass housing provision in 2002 (see Figure 14). Besides the political support, availability of public lands is also chosen as a determinant factor in this study. The provinces in where the state occupies relatively more areas are Karabuk ( 75 percent), Kastamonu (66 percent), and Kocaeli (66 percent). The average share of public lands in total is 27 percent (see Figure 9).

Variables in the second model consist of net migration change, the ratio of closed real estate companies, total land use for housing, and the average election results in the same period with mass housing provision of TOKI. The percentage change in net migration between 2000 and 2011 shows a positive trend in most eastern part of Turkey. 
The data shows that the net migration at most eastern provinces is negative while other provinces, especially the ones in the west, have positive net migration. Thus, the increase of net migration in the east (from minus to minus value) and the decrease of net migration in the west (from positive to positive value) basically indicates that the pace of westbound migration has decreased over time (see Figure 11).

Similar to the 2002 general election, the ruling administration increased their political support in the same provinces. The mean value of the average results in 2007 and 2011 elections (49 percent) is higher than that of 2002 election ( 33 percent).

Total land use for housing between 2002 and 2011 is relatively higher in the middle and western parts of Turkey. The geographical features of these areas in fact allow more land consumption than other regions as their altitudes are considerably lower. The provinces with largest land consumption are primarily Ankara (79 square $\mathrm{km}$ ), Istanbul (48 square $\mathrm{km}$ ), and Izmir (27 square $\mathrm{km}$ ), which are the most populated cities in Turkey (see Figure 13).

On average, 28 percent of registered real estate companies and housing cooperatives in 2002 terminated their operations in the period of 2002 and 2009 throughout the country. The provinces with highest rate of closures are Konya and Erzurum where the number of closures even goes beyond the total number of registered companies in 2002. The least affected provinces are Kirikkale, Kirsehir, Siirt, and Hakkari, in where economic activities are relatively low (see Figure 12).

There are 8 provinces that were hit by a major earthquake between 1980 and 2003. These provinces are Erzurum (M: 6.9, 1983), Erzincan (M: 6.8), Afyon (M: 6.1, 
1995; M: 6.5, 2002), Adana (M: 6.2, 1998), Kocaeli (M: 7.4, 1999), Duzce (M: 7.2, 1999), Tunceli (M: 6.1, 2003), and Bingol (M: 6.4, 2003).

Finally, the 16 provinces with metropolitan municipalities are Adana, Ankara, Antalya, Bursa, Diyarbakir, Erzurum, Eskisehir, Gaziantep, Mersin, Istanbul, Izmir, Kayseri, Kocaeli, Konya, Sakarya, and Samsun. 
Figure 7. Mass housing units by TOKI per 1000
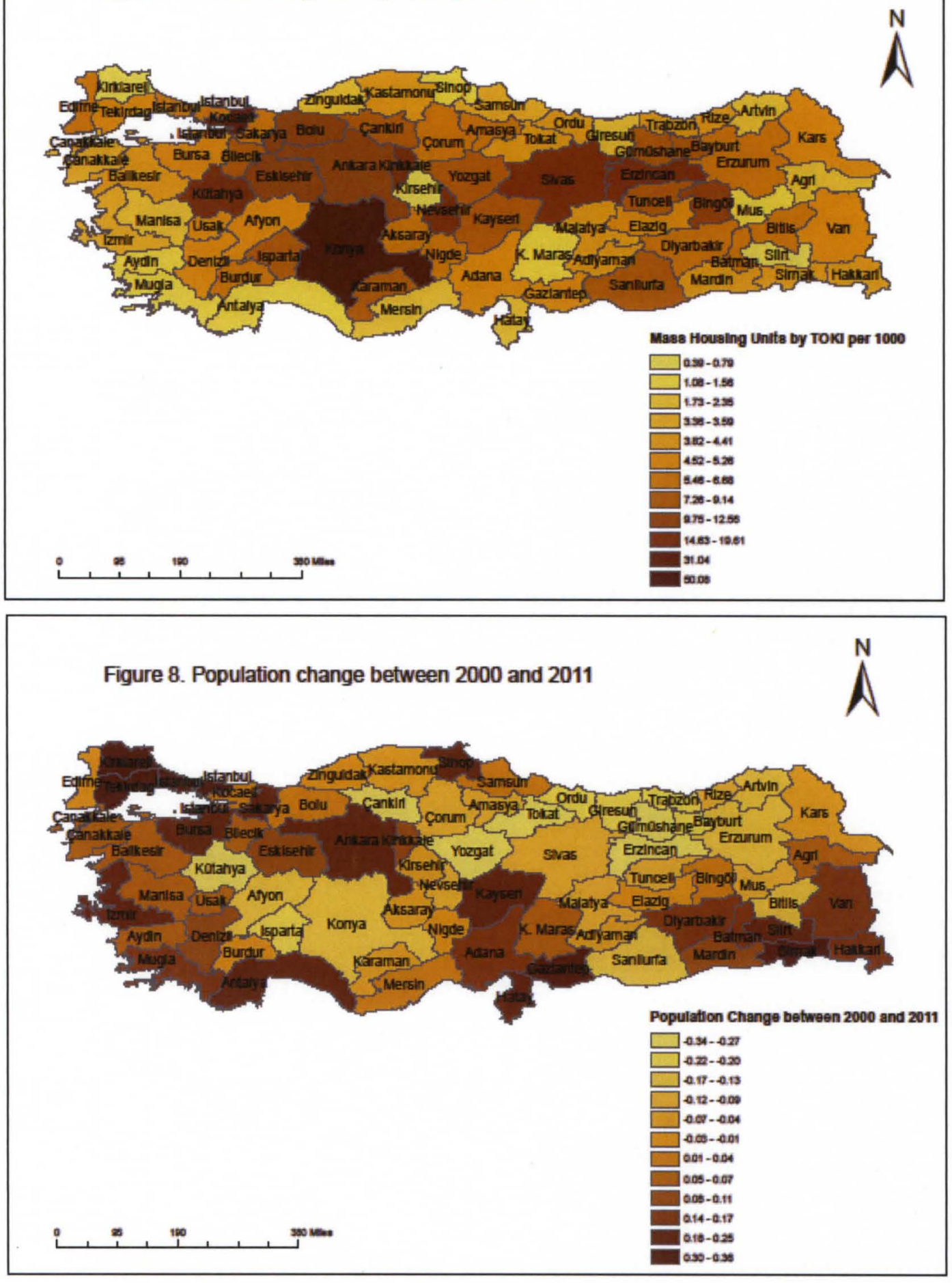

Source: The Turkish Statistical Institution 

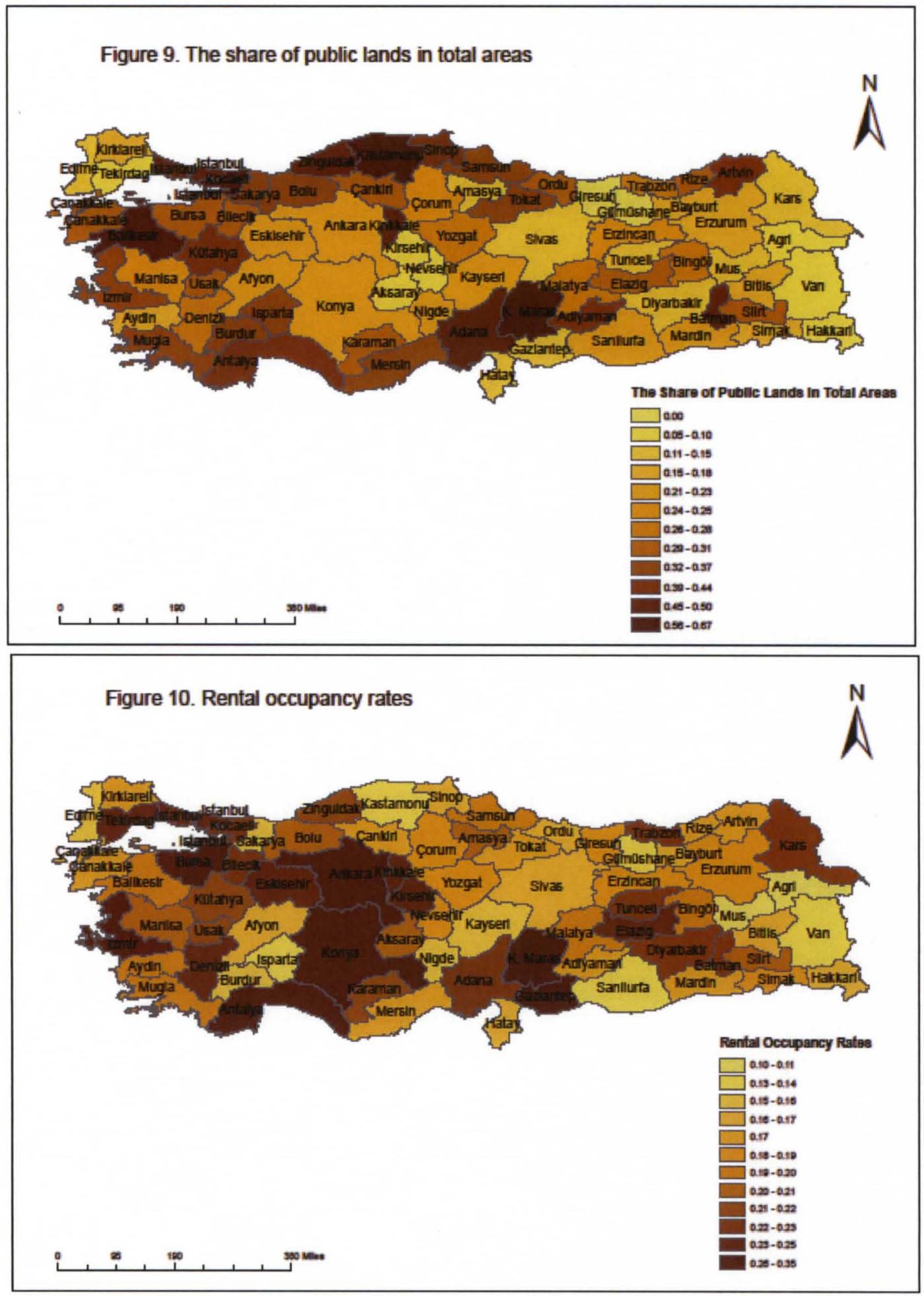

Source: The Turkish Statistical Institution 


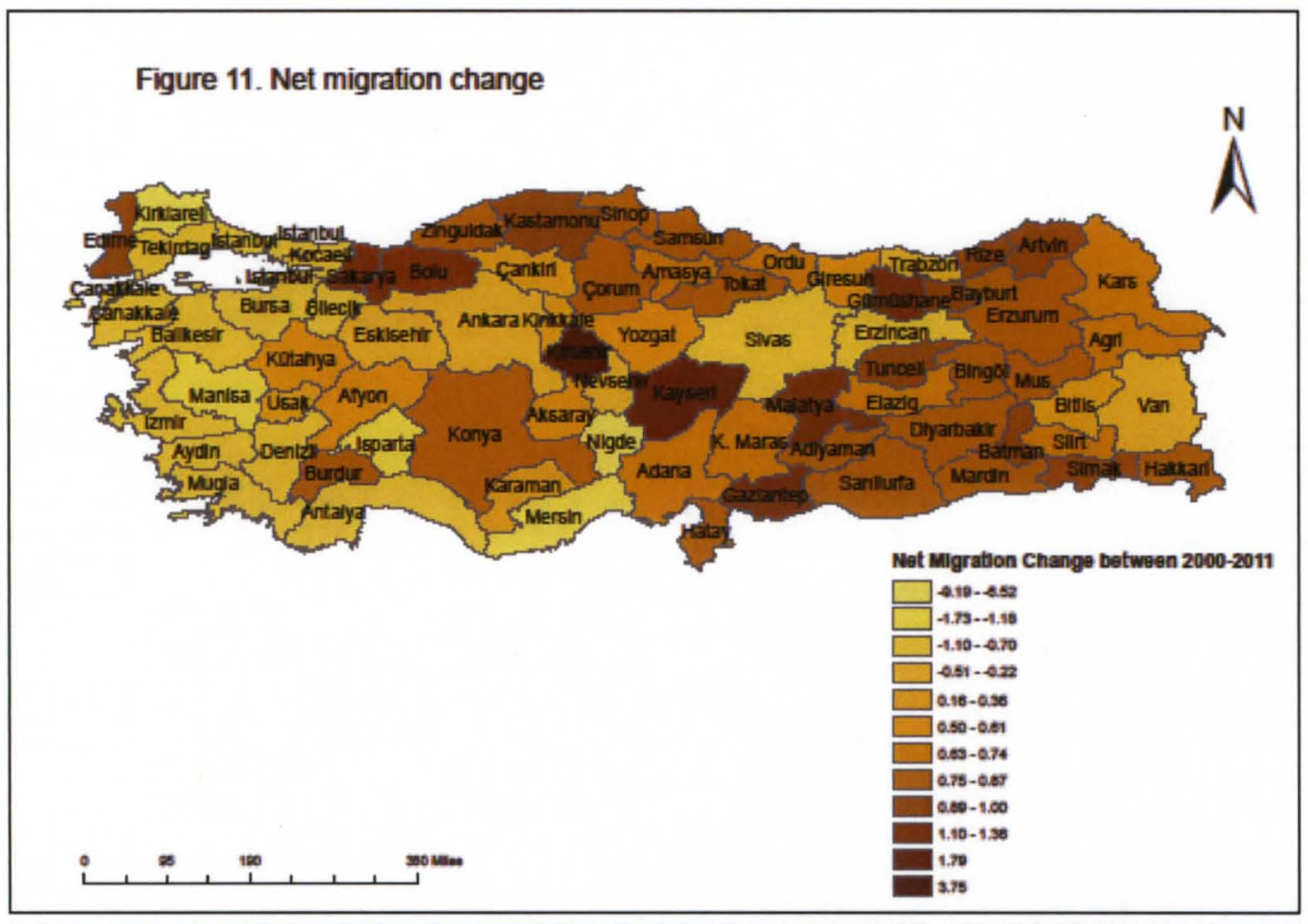

Figure 12. The rate of closed real estate companies
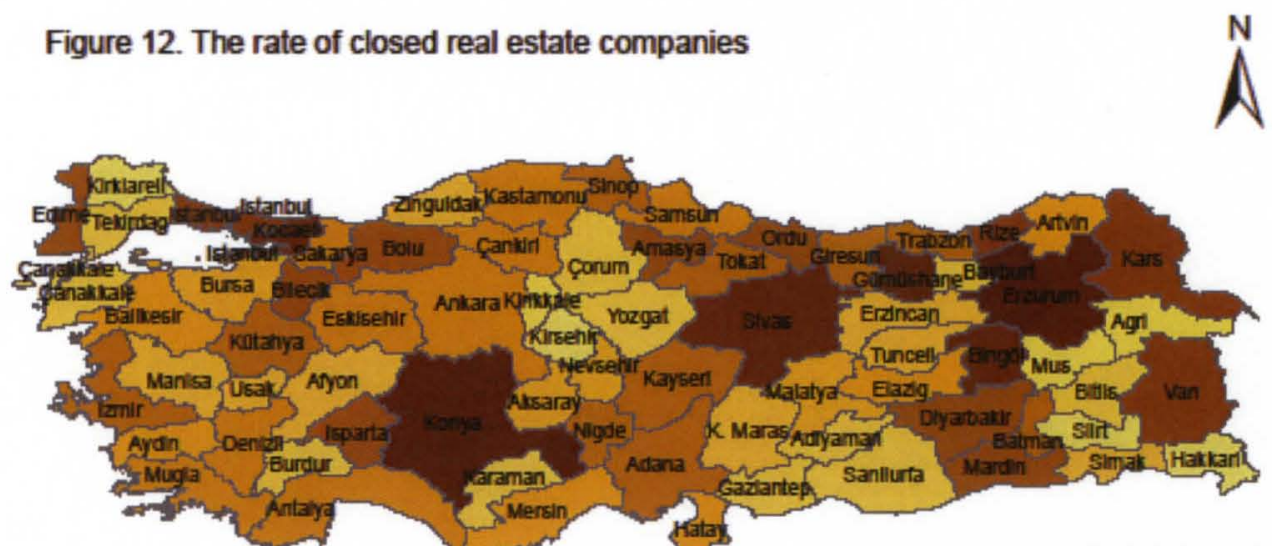

The Rate of Closed Real Estate Companles

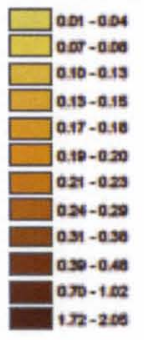

Source: The Turkish Statistical Institution 


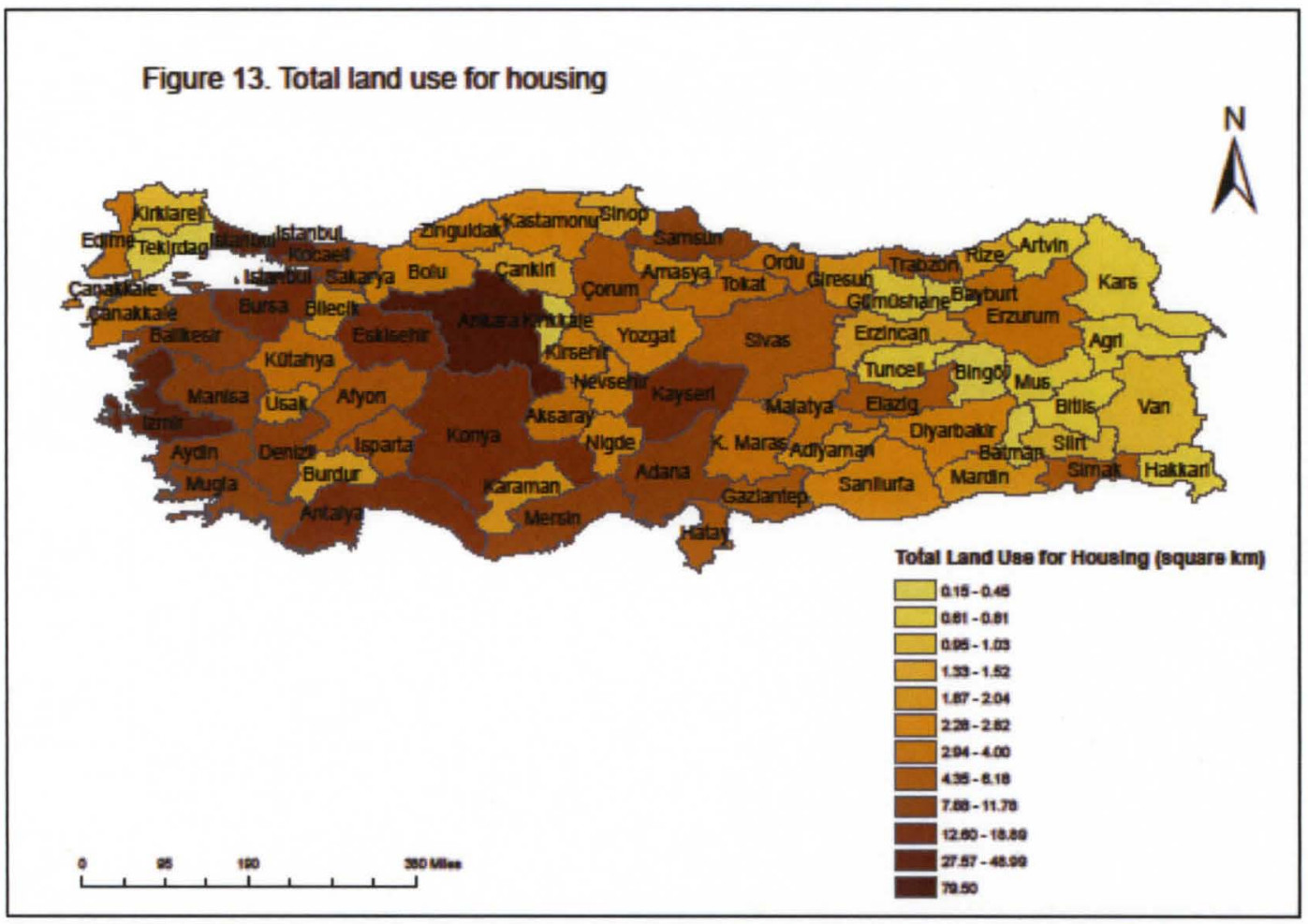

Figure 14. General election results for the ruling administration (in 2002, 2007, and 2011)
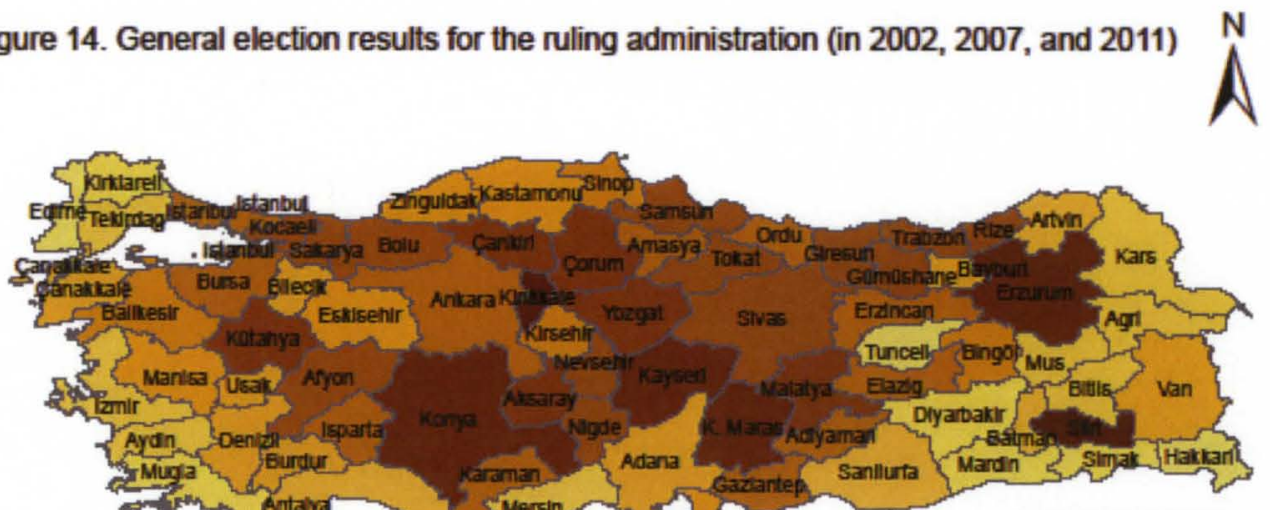

General 日ection Rebults for the Fuiling Admininistration (in 2002, 2007, and 2011)

$\stackrel{0}{2}, \frac{100}{1}, \ldots, \ldots$

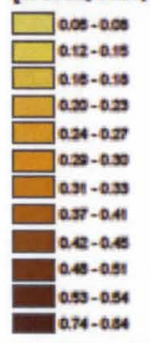

Source: The Turkish Statistical Institution 


\section{CHAPTER VIII}

\section{RESULTS}

As indicated in the previous chapter, this study examines the determinants and possible impacts of last decade's mass housing implementations. It is hypothesized that recent mass housing provision is selective on particular factors that are considerably homeownership status, high population rates, political support and available public lands; on the other hand, the increasing number of mass housing settlements has an impact on real estate market, the level of land use for housing, migration level and political success of the ruling administration.

\section{$\underline{\text { Bivariate Relationships (Model I) }}$}

Table 8 shows the correlation matrices for all variables examined in the regression analysis. In the model, there are no significant correlations among the independent variables except that the population change, metropolitan areas and tenancy rate are significantly correlated. In terms of the link between the dependent variable and independent variables, mass housing units per thousand is positively correlated with the political support (2002 election: $r=0.329)$, metropolitan municipalities $(r=0.239)$, and earthquake $(r=0.268)$. 
Table 8. Correlation matrix, dependent and independent variables for model I, N=81

\begin{tabular}{|c|c|c|c|c|c|c|c|}
\hline & $\mathrm{X} 1$ & $\mathrm{X} 2$ & $\mathrm{X} 3$ & $\mathrm{X} 4$ & $\mathrm{X} 5$ & X6 & $X 7$ \\
\hline X1 Housing Units by TOKI (per 1000) & 1 & & & & & & \\
\hline X2 Population Change $\%(2000-2011)$ & -.211 & 1 & & & & & \\
\hline X3 The Ratio of Public Lands in Total \% & .085 & .092 & 1 & & & & \\
\hline X4 General Election Results for the Ruling Party \% (2002) & $\begin{array}{l}.329 \\
(* *)\end{array}$ & -.245 & .224 & 1 & & & \\
\hline X5 The Ratio of Tenancy in Total Households \% (2000) & .171 & $\begin{array}{l}.361 \\
(* *)\end{array}$ & .187 & .086 & 1 & & \\
\hline X6 Earthquake (1980-2003) & $\begin{array}{r}.268 \\
\left(^{*}\right)\end{array}$ & -.117 & .098 & .073 & -.022 & 1 & \\
\hline X7 Metropolitan Municipalities (by 2009) & $\begin{array}{c}.239 \\
\left({ }^{*}\right)\end{array}$ & $\begin{array}{l}.371 \\
(* *)\end{array}$ & .139 & .082 & $\begin{array}{l}.436 \\
\left({ }^{* *}\right)\end{array}$ & .147. & 1 \\
\hline
\end{tabular}

** Correlation is significant at the 0.01 level (2-tailed)

* Correlation is significant at the 0.05 level (2-tailed) 


\section{$\underline{\text { Regression Analysis (Model I) }}$}

In the first model, the level of mass housing settlements is regressed on the population change between 2000 and 2011, the ratio of public lands in total areas, general election results for the ruling party in 2002 , the ratio of tenancy in total households, and whether the observation has a background of earthquake or metropolitan municipality (see Table 9). Due to significant collinearity between the population change, the tenancy rate, and the metropolitan municipalities, the model is examined in four different equations to see those variables' predicting power separately. The findings show that only 26 percent of variation in housing provision can be explained by the determinants at .001 level. Based on our hypothesis, the coefficients are expected to be positive values. According to the results, the political support, the provinces' earthquake history, and metropolitan municipalities seem to be motivating factors for TOKI's mass housing practices when all other elements are set equal. A one unit increase in political support gave the provinces 11.5 times more housing provision. Also, TOKI's initial principal, which is "making everyone a homeowner", cannot be validated at a significant level but the administration's mass housing production seems to have prioritized the provinces with metropolitan municipalities, which have relatively more rental occupancy rates. Accounting for the multi-collinearity of the independent variables, the coefficient of metropolitan municipalities and its significant level slightly decrease when these independent variables are examined separately.

On the other hand, the provinces with high population increase between 2000 and 2011 seem to have less mass housing unit per capita. However, the independent variable of population change is significantly correlated with the tenancy rate and the metropolitan 
municipalities, and it does not have a significant relationship with the mass housing provision when the multi-collinearity problem is fixed. Although TOKI produces a significant number of housing units for all provinces, the mass housing units per capita are much higher in the central parts of the country while population increase usually occurs in other regions. In theory, housing provision should follow the demand-supply rule, and more population increase means more housing stock is needed. The findings do not show any significant connection between the population change and the mass housing provision as they validate the claim that TOKI does not take into account the demographic features of the provinces and the level of local housing demand in its projects.

The provinces with a major earthquake history between 1980 and 2003 seem to have received more mass housing units since their housing stocks decreased due to such destructive earthquakes.

In the final examination of the regression model, more available public lands do not seem to give extra motivation to TOKI. It is commonly argued that the administration overuses the public lands for its housing provision. The finding shows that the ratio of public lands is not an explanatory factor in mass housing provision at a significant level. 
Table 9. Regression Analysis (Model I)

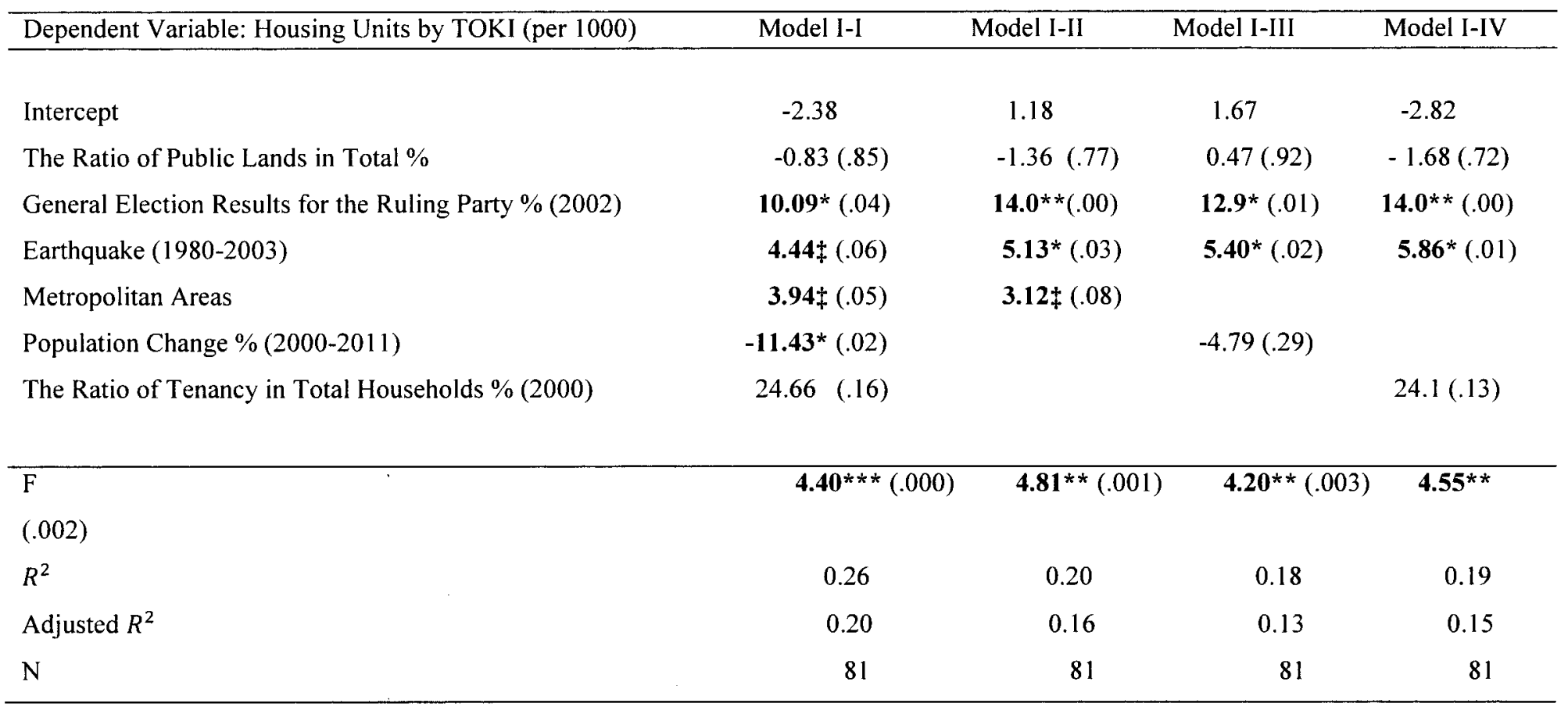

Notes: Unstandardized coefficients ( $p$-value); significant predictors in bold.

$\ddagger \mathrm{p}<0.1 * \mathrm{p}<0.05 * * \mathrm{p}<0.01 * * * \mathrm{p}<0.001$ 


\section{$\underline{\text { Bivariate Relationships (Model II) }}$}

In the second model, it is hypothesized that the mass housing provision influences the net migration, the real estate sector, total land use for housing, and the average election results.

The findings show that the TOKI projects damage the real estate sector. The ratio of closed real estate companies has an increasing trend as per capita housing unit by TOKI becomes higher. Correlation coefficient between them is 0.644 at the 0.01 level (see Table 10). The role of TOKI as a single actor in housing provision has always been among the critiques. In its operations, the administration takes most of the advantages that are not available to other private actors. The model validates that the recent mass housing productions results with business closures in the housing market.

The model also shows that TOKI has brought more political support to the administration in the following years of its first initiatives. The correlation coefficient for the average results in 2007 and 2011 elections and the mass housing units per thousand is 0.644 and statistically significant at 0.05 level.

The argument that the mass housing authority allocates too much land space to its housing provision has no ground in this study's findings. There is no significant relationship between the mass housing provision and total land use for housing in the period between 2002 and 2011. As indicated in the previous chapter, the land consumption of housing settlements seems to be higher in the western and middle parts of the country which have relatively lower altitudes (see Figure 13). 
Finally, the mass housing provision does not influence the net migration according to the bivariate relationship analysis. However, as the eastern provinces started to have more mass housing projects, their out-migration toward the west and the metropolitan areas slowed down. Figure 11 in the previous chapter shows that the most eastern provinces increased their net migration level from far lower minus values in 2000. 
Table 10. Correlation matrix, variables for model II, $N=81$

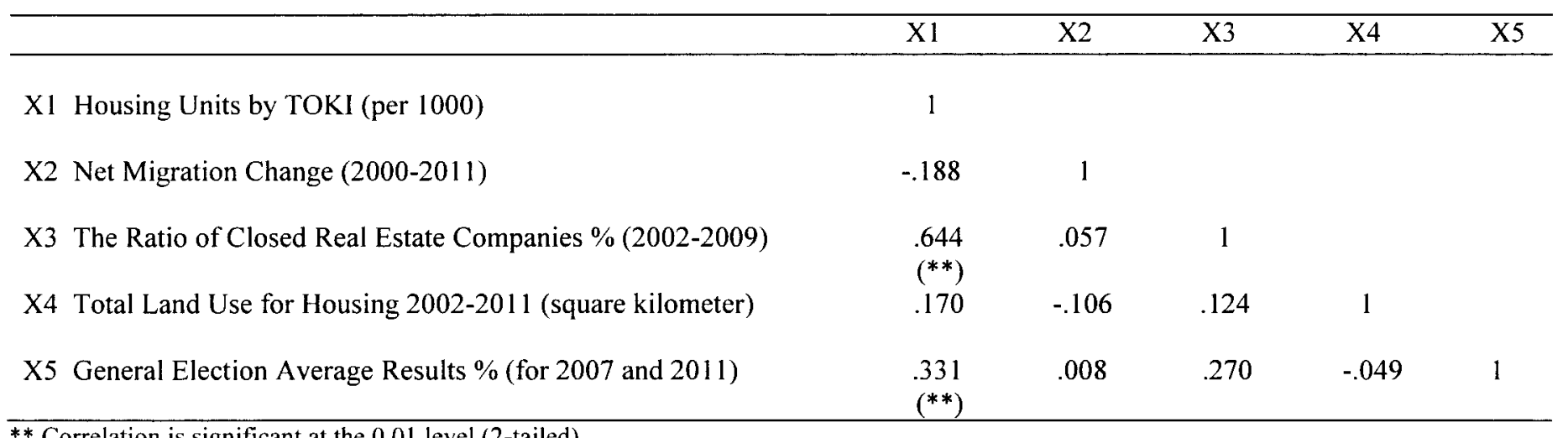

** Correlation is significant at the 0.01 level (2-tailed)

* Correlation is significant at the 0.05 level (2-tailed) 


\section{CHAPTER IX}

\section{CONCLUSION}

Government subsidies to housing have become prevalent since the industrial revolution changed the production system in the economy and turned production and transportation hubs into arrival points of migration, making cities the most populated human ecologies. As population growth occurred in most industrial cities, demands for shelter have become more intense but the existing housing stocks have not been able to meet such needs. Thus, the quantitative difference between the current housing stocks and the increasing demands for housing hand in hand with inadequate housing provision of the market economy, and qualitative deficiencies related to these factors, can generally be included in the definition of housing problem.

Also, housing is considered to be one of the most essential needs of human beings. Recently, many international institutions have become concerned with housing issues as part of their missions. Most state documents and international agreements, today, recognize housing as a right and extend its definition to certain quality standards.

To mitigate inadequacy of housing provision, especially for low income households, government organizations implement many housing policies as part of their

duties since the market economy does not function perfectly to meet the increasing 
demand of housing at affordable prices. In result, states take necessary measure of providing affordable housing for the well-being of individuals.

In Turkey, housing problems have started to rise in the 1950s when industrialization and urbanization accelerated. As such, housing provision in Turkey has developed under the effect of this unprecedented population movement due to migration from rural to urban areas. Thus, a dual system emerged in the housing sector, that is, authorized housing was built in planned areas of cities, and on the other hand, illegal housing (squatter settlements) was expanded on public lands. The problem of inadequate housing supply for low and middle income families was addressed by the enactment of two Mass Housing Laws. In the 1980s, housing provision was implemented in a mass quantity by housing cooperatives that were mostly subsidized by TOKİ.

The authority and resources of the administration was broadened with some new regulations in the past decade. TOKI gained the authority to have projects and investments to generate profit so that its resource base could be afforded under the name of revenue sharing projects. Moreover, all duties and resources of the Land Office were transferred to TOKI by law. This situation increased the land stock of the administration unexpectedly. Apart from these regulations, by the law amendments in 2004, TOKI became authorized to make local plans for the areas where its mass housing provision takes place. These areas were determined as housing development zones. By this way, the administration attained a special planning authority which basically gives a way the use of public lands. With all these regulations, the administration also obtained regulatory and investor roles, and was exempt from most administrative responsibilities of a private 
company. Therefore, it is possible to state that the housing provision of TOKI is a kind of government supported monopoly in the sector (Geray, 2009).

On the other side of the coin, the recent mass housing provision of TOKI is mostly appreciated by its beneficiaries. More than 200,000 families have become homeowners by the advantages of this affordable housing provision. TOKI has offered houses to different income levels, with five to ten-year mortgages and the interest being set to the wage increase.

Almost all critiques are built upon the fact that TOKI's practices focus only on narrowing the housing gap by producing housing units at a mass level. By doing so, the qualitative aspects of these buildings are usually taken as given, and the administration does not pay attention to the geographical features of a region when applying its housing provision throughout the country. Its excessive use of public lands and monopolistic role in the real estate market also receive critiques from scholars and civil organizations.

In general, this thesis focuses on the mass housing provision's possible determinants and outcomes. Based on discussion in the literature, it is hypothesized that population increase, political support, available public lands, and tenancy rates are the determining factors; net migration increase, real estate company shutdowns, more land use for housing, and more political support to the administration are the possible outcomes of mass housing provision by TOKI.

The findings of this study indicate that the mass housing provision of the past decade is a positive function of political gains, metropolitan areas, and the destruction of recent major earthquakes. Besides this, the study found no significant relationship 
between mass housing provision and the available public lands to validate the discussion in the literature regarding it. On the other hand, the rental occupation rate by itself is not a determining factor on mass housing provision but overlaps with metropolitan municipality which is a positive factor of the mass housing projects. Finally, TOKI does not seem to pay attention to the population increase as its mass housing provision is not in the same direction with such demographic change.

In terms of the impacts, the recent housing provision of TOKI does seem to be affecting the private sector in a negative way. There are more closed real estate companies and cooperatives in the provinces where mass housing unit per capita is relatively higher. On the other hand, any change in net migration is not significantly correlated with the mass housing provision but the pace of out-migration in the east seems to have slowed down between 2000 and 2011 as the eastern provinces began to have mass housing projects.

This study aims to fill the empirical gap in the subject of mass housing by assessing the driving factors and influences of the recent mass housing provision. The mass housing is still young in Turkey and TOKI administration is planning to double the number of its current housing provision in the future. In this manner, more empirical studies are needed to reveal possible outcomes of the mass housing. 


\section{REFERENCES}

Akcay, B. (2003). "An Assessment of the Housing Finance Strategies in Turkey". The Journal of Academic Research, 5 (18): $45-55$ [in Turkish].

Antalya Chamber of Architecture (2008). TOKI Report [in Turkish].

Ayan, E. (2011). "Housing Finance System and Analysis of the Applications of Housing Development Administration of Turkey". The Journal of Accounting and Finance (July) [in Turkish]

Aydin, S. (2003). "Economic Aspects of Housing Problems in Turkey", Ankara, Dissertation Submitted to Ankara University [in Turkish].

Balchin, P. (1996). Housing Policy in Europe. London and New York, Routledge.

Baysal, C. U. (2010). "Voluntary-Involuntary Ghettos". The Journal of Radical Two (14) [in Turkish]

Besikci, I. (1992). The Order of Eastern Anatolia: Socio-Economic and Ethnic Elements. Ankara, Yurt Kitap Publication [in Turkish].

Boratav, K. (1990). "History of Economy: 1908-1980". In Aksin, S. (ed), Turkish History 4: Cagdas Turkiye. Istanbul, Cem Publication, pp. 263-254 [in Turkish]. 
Boratav, K. (1995). "History of Economy: 1981-1994”. In Aksin, S. (ed), Turkish

History 5: Today's Turkey. Istanbul, Cem Publication, pp. 159-213 [in Turkish].

Capa, M. (1990). "The Settlement of the Migrants from Greece”. Ataturk Yolu (5) [in Turkish].

Coban, A. N. (2012). "Housing Policies from the Proclamation of the Republic to the Present”. Ankara: Ankara University SBF Journal, 67 (3): 57-90 [in Turkish].

Geray, C. (2009). "Implementations of TOKI in terms of Social Housing Policy". Istanbul: Turkish Chambers of Architecture. Evaluations on the Works of TOKI, pp. $77-87$ [in Turkish].

Gokmen P. G. and A. Ozsoy (2008). "Emerging Trends and Problems of Housing Supply in Urban Housing Transformations in Istanbul". Paper presented to Institute of Australian Geographers Conference. University of Tasmania. Hobart, Australia.

Gumus, K. (2010). "What Does the President Advocate?" The Journal of Radical Two (8) [in Turkish].

Gur, M. (2012). "Identity Problem: TOKI Houses". Paper presented to $6^{\text {th }}$ National Housing Roofs and Fronts Symposium, Bursa [in Turkish].

Gur, M and N. Dostoglu, (2010). "Satisfaction Research in TOKI Houses for Low and Middle Income in Bursa". Uludag University Engineering-Architecture Faculty Review, 15 (2): 149-153 [in Turkish]. 
Harsman, B. and J. M. Quigley (1991). "Housing Markets and Housing Institutions in a Comparative Context". In B. Harsman and J. M. Quigley (eds), Housing Markets and Housing Institutions: An International Comparison. Boston, Kluwer Academic Publishers.

Harvey, J. (1981). The Economics of Real Property. London, Macmillan Press.

Isik, S (2006). "Urbanization and Urbanization Models in Turkey". Izmir: The Journal of Aegean Geography, 14: 57-71.

Kara, M and H. Palabiyik (2009). "Housing Policies in Turkey After 1980: Mass Housing Administration (TOKI) Gecekondu Transformation Cases". Paper presented to International Davraz Congress, Isparta [in Turkish].

Karpat, K. H. (1976). The Gecekondu: Rural Migration and Urbanization. Cambridge University Press.

Keles, R. (1983). Turkish Urbanization, Housing and Gecekondu in Ten Questions, $3^{\text {rd }}$ Edition. Gercek Publication [in Turkish].

Keles, R. (2010). Urbanization Policies, $11^{\text {th }}$ Edition. Ankara: Imge Publication [in Turkish].

Keles, R., R. Hamamci, and C. Coban (2009). Environmental Policies, $6^{\text {th }}$ Edition. Ankara: Imge Publication [in Turkish].

Koc, N. and M. Inan (2012). "Transformation with Dynamite". Vatan Newspaper (October) [in Turkish]. 
Kumkale, T. (2009). "Sustainability of Housing: 'Houses' Thematic Network as a Management and Renovation Research". Mass Housing Architecture: Experiences, Opportunities, and Possibilities, Ankara [in Turkish].

Kurtoglu, A. (2005). Town Fellowships and Politics in Cities. Istanbul: Iletisim Publications [in Turkish].

Mass Housing Administration (2010-2011). Building Turkey of the Future. Ankara. Corporate Profile, pp. 5-85.

Meric, K. (2010). “The Loot of Urban Renewal and The Struggle of Urban Poor's Housing Right". Paper presented to Land Property Symposium. Ankara, Memleket Publications, pp. 632-640 [in Turkish].

Oxley, M. (2000). The Future of Social Housing: Learning from Europe. London: Institute for Public Policy Research.

Oymen, A. (1985). "Housing as Housing", Milliyet, Writing Series (9) [in Turkish].

Ozkan, M. (2009). "A General Overview on Turkish Housing Finance System". The Journal of Budgetary World (32): 4-19 [in Turkish].

Ozturk, N. and A. Dogan (2010). "Problems of the Housing Sector and Propositions for a Solution”. The Journal of Budgetary World, 33: 139-154 [in Turkish].

Pollmark R\&D Company (2010). TOKI Consumer Consultation Process, Satisfaction Analysis. Ankara [in Turkish]. 
Sandikci, M (2012). "Flood Disaster in Samsun: Nine Casualties". Dogan News Agency (4 July) (http://www.hurriyet.com.tr/gundem/20910915.asp) [in Turkish].

Savran, S. (1992). Class Struggle in Turkey, 1919-1980. Istanbul, Kardelen [in Turkish].

Sengul, T. (2001). Urban Irony and Politics: The Process of Capitalist Urbanization. Istanbul, WALD [in Turkish].

Tavsanoglu, L. (2012). "TOKI Became the Name of Unearned Income Transfer", Cumhuriyet Newspaper (8 July) [in Turkish].

Tekeli, D. (2008). "The Principals Affecting the Architecture in TOKI Projects". Housing and TOKI Architecture in Anatolia, Technical Investigation-PanelForum. Konya: TMMOB Chamber of Architecture, pp. 54-58 [in Turkish].

Tekeli I. (1996). The Development of Housing Problem in Turkish Life and Literature. Mass Housing Administration, Housing Study Series, (2) [in Turkish].

Tomruk, B. (2009). "Architectural and Urban Transformation Dynamics of Bursa". In H. Kahvecioglu (ed), The Changing Face of Anatolian Urban Places. Ankara, Architecture 344. pp. 29-33 [in Turkish].

Tuna, B. (2009). "To Whom and How TOKI Build Houses". In Evaluations on the Works of TOKI. Ankara: Turkish Chambers of Architecture, pp. 71-76 [in Turkish].

Turel, A. (2006). Principals of Housing. Lecture Notes of 2006-2007 Spring Term. Ankara, METU [in Turkish]. 
Uzun, C. N. (2005). "Transformation of Housing Areas in Ankara: Urban Transformation Projects". In T. Senyapili (ed), The 'Ankara' of the 'Republic': A Present to Ozcan Altaban. Ankara, METU Publication, pp. 198-215 [in Turkish].

Vale, L. J. (2002). Reclaiming Public Housing: A Half Century of Struggle in Three Public Neighborhoods. Cambridge, MA. Harvard University Press.

Whitehead, C. (2007). Social Housing in England. In C. Whitehead and K. Scanlon (eds), Social Housing in Europe. London, LSE Publications.

Yuksel, Y.D and G.P. Gokmen (2008). "Changing of Mass Housing Production by the Government in Turkey". Paper presented to ENHR International Conference of Changing Housing Markets: Integration and Segmentation, Prague [in Turkish]. 


\section{CURRICULUM VITAE}

NAME: $\quad$ Salih Ozgur Sarica

$\begin{array}{ll}\text { ADDRESS: } & \text { Tellioglu Sit. C Blok } \\ & \text { D.1 Denizli, Turkey 20020 } \\ \text { DOB: } & \text { Denizli, Turkey - May 5, 1983 } \\ \text { EDUCATION } & \\ \text { \& TRAINING } & \text { M.S. Public Management } \\ & \text { Kocaeli University, Turkey } \\ & 2006-2008\end{array}$

